\title{
STAVEBNÍ PROMĚNY HRADU ORLÍKA NAD VLTAVOU V 16. STOLETÍ
}

\author{
JIŘÍ VARHANÍK
}

Abstrakt: Příspěvek rekapituluje stavební vývoj hradu ve středověku do požáru v roce 1508 a jeho interpretace v dosavadni literatuře. Shrnuje poznatky o pozdně gotické přestavbě v letech 1515-1520 a následujicích renesančnich úpravách z 80. let 16. století, kdy byl hrad zvýšen o druhé patro, z nichž se však zachovalo jen velmi málo detaili̊, zejména $v$ důsledku požáru z roku 1802 a rozsáhlé klasicistní přestavby.

Klíčová slova: hrad - pozdní gotika - renesance - sklipková klenba - kaple - jižni Čechy - páni ze Švamberka.

\section{Building Transformations of Orlik nad Vltavou Castle in the 16th Century}

Abstract: This contribution charts the building development of the castle in the Middle Ages, prior to a fire in 1508 and its interpretations in existing literature. It sums up findings about the late-Gothic reconstruction of the castle in 1515-1520 and the following renaissance refurbishment in the 1580s when another storey was added to the castle. However, few details about this modification have survived, owing to a fire in 1802 and extensive classicist reconstruction.

Key words: castle - late Gothic - renaissance - barrel vault - chapel - southern Bohemia - lords of Švamberk.

\section{Úvod}

Zámek Orlík patři ke známým a navštěvovaným památkám. Většina jeho návštěvníků, jejichž zájem se upíná k bohatě vybaveným interiérům, sotva zaznamená celou řadu detailů dokládajících složitý stavební vývoj objektu. V minulých dvou desetiletích se podařilo na základě poznatků ze stavebněhistorických pozorování a archeologických výzkumů podstatně korigovat a doplnit pohled dosavadní literatury na stavební vývoj zdejšího hradu ve středověku. Přesto se však jeho počátky jednoznačně objasnit zatím nepodařilo.

Nejstarší zprávy písemných pramenů, které Orlík zmiňují, jsou obsaženy ve formulářové sbírce biskupa Tobiáše z Bechyně

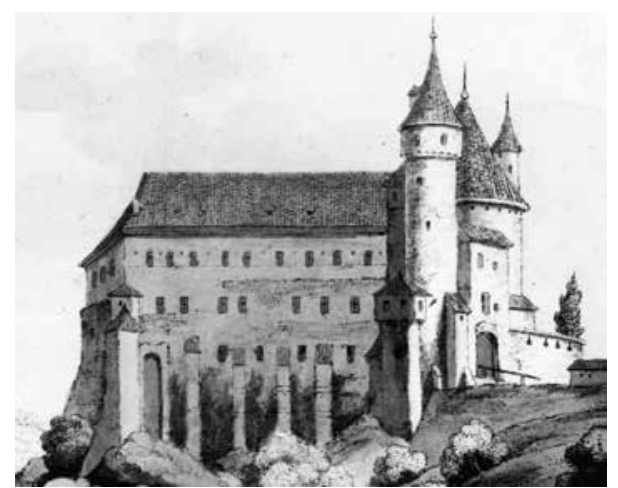

Obr. 1. Hrad Orlík, okr. Písek, rytina W. Bergera podle kresby F. K. Wolfa z roku 1787, výřez.

Abb. 1. Burg Orlík, Bezirk Písek, Kupferstich von W. Berger nach einer Zeichnung von F. K. Wolf aus dem Jahr 1787, Ausschnitt.

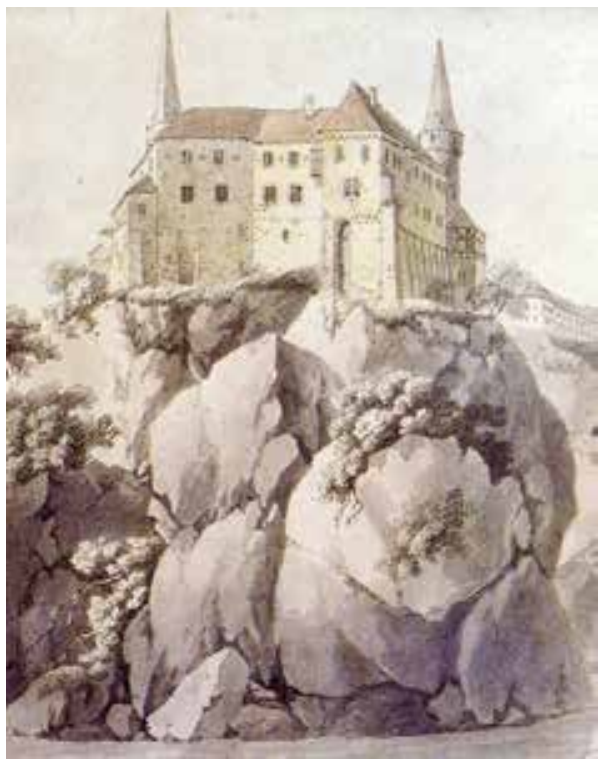

Obr. 2. Hrad Orlík, okr. Písek, před požárem v roce 1802, kolorovaný lept K. Postla podle kresby L. Janschy, výřez. Abb. 2. Burg Orlík, Bezirk Písek, vor dem Brand im Jahr 1802 , kolorierte Radierung von K. Postl nach einer Zeichnung von L. Janscha, Ausschnitt. 
(Novák 1903, 25-27, 95, 96, č. 28, 29, 117, 118). Pocházejí z let 1288-1289, kdy odtud posádka Zdislava ze Šternberka napadla biskupské statky. Nic není známo o osudech Orlíka v první polovině 14. století; lze předpokládat, že byl za vlády Jana Lucemburského zastaven, podobně jako většina královských hradů.

Souvislejší zprávy o držitelích hradu, počínající po polovině 14. století, shrnul již A. Sedláček $(1936,60)$. Roku 1357 Karel IV. Orlík postoupil svému významnému dvořanu, mindenskému biskupovi Dětřichovi z Pordic, který byl též vyšehradským proboštem, královským kancléřem a záhy se stal magdeburským arcibiskupem. Již v roce 1360 byl hrad s přívozem a clem udělen v manství jeho stejnojmennému synovci s podmínkou, že pro případ války má být otevřen králi. Listinou vydanou v Budyšíně roku 1369 byl Orlík s př́íslušenstvím udělen v manství Hyncíkovi Pluhovi z Rabštejna (AČ II, 186 č. 328), který jej se souhlasem krále roku 1395 směnil se Zikmundem Hulerem za nevelký hrad Boršengrýn na Chebsku (AČ II, 201 č. 419). V této souvislosti se Orlík uvádí pouze jako tvrz. V roce 1401 král Václav IV. u svého podkomořího Hulera na Orlíku pobýval (Sedláček 1936, 60). Po Hulerově pádu roku 1405 přešel Orlík na jeho bratra Ondřeje, který jej se souhlasem krále převedl na nejvyššího mincmistra Petra Zmrzlíka ze Svojšína (AČ II, 187 č. 329). Zmrzlíkové drželi Orlík více než jedno století. Roku 1508 hrad vyhořel, Václav Zmrzlík se přestěhoval na Lnáře, u krále dosáhl zproštění manských závazků a poté opuštěný hrad prodal v roce 1514 Kryštofovi ze Švamberka. V majetku Švamberků Orlík zůstal až do roku 1621, kdy byl po porážce stavovského povstání obsazen císařskou posádkou, zkonfiskován a posléze roku 1623 prodán Janu Oldřichu z Eggenberka (Sedláček 1936, 62-64). Po Eggenbercích, kteří hrad využívali pouze jako správní středisko panství, Orlík zdědili roku 1719 Schwarzenberkové. Ani ti zde v 18. století nesídlili, nicméně provedli určité stavební úpravy hradu, intenzivní stavební činnost naproti tomu probíhala na předhradí. Po oddělení mladší větve rodu v roce 1800 se starý hrad stal jejím sídlem, avšak v průběhu přestavby roku 1802 vyhořel. V 19. století došlo k nevelkým, převážně interiérovým úpravám. V letech 1958-1962 bylo prováděno rozsáhlé statické zajištění v souvislosti se zaplavením vltavského údolí v důsledku výstavby Orlické přehrady (Budinka 1959).

\section{Hrad ve středověku a jeho poznání}

Hrad byl situován na strmé skalní ostrožně nad pravým břehem Vltavy, kterou odděloval od předpolí masivní skalní výchoz, dodnes sahající až do výše prvního patra. Plocha ostrožny

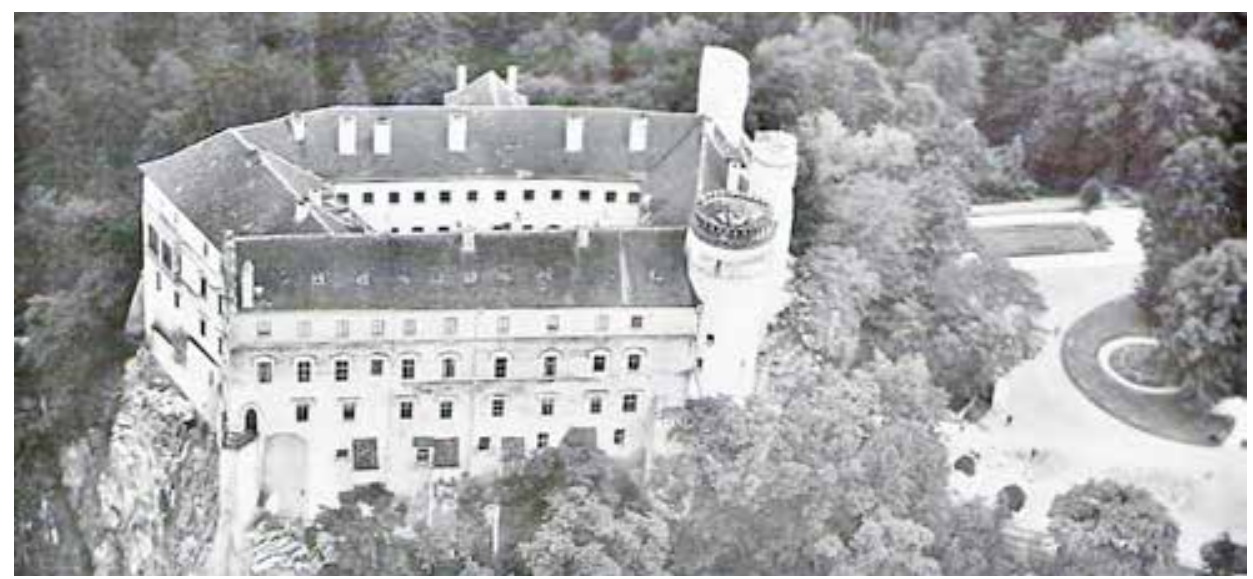

Obr. 3. Hrad Orlík, okr. Písek. Letecký pohled od severozápadu z počátku 20. let minulého století.

Abb. 3. Burg Orlík, Bezirk Písek. Vogelperspektive von Norwesten zu Beginn der zwanziger Jahre des vergangenen Jahrhunderts. 
byla nerovná a výrazně klesala směrem k severozápadu. Před čelním skalním výchozem byl vylámán př́íkop.

Již starší literatura identifikovala ve stavebním organismu hradu některé jeho části, přičítané výstavbě 13. a 14. století. Šlo zejména o úseky obvodní hradby, palác na zadní straně ostrožny a jihovýchodní křídlo, v němž se dochovala přízemní prostora se dvěma poli křížové klenby s klínovými vyžlabenými žebry, která vybíhají z jednoduchých jehlancových konzol. Na křižzné žeber se uplatňují ploché neprofilované svorníky. Západní okrouhlá věž vlevo od vstupu byla považována za bergfrit (Kostka-Hanesch 1956, 1). Tento názor v podstatě převzala $\mathrm{D}$. Menclová (1972, 1, 163-165) ve své syntetické práci o českých hradech, přičemž uvedla, že využití skalního masivu v čele hradu připomíná hrady se štítovou zdí. V publikovaném půdorysu hradu je nevelká stř̌ední věž chybně situována do parkánu.

Podrobnější poznatky přinesl až stavebněhistorický průzkum SÚRPMO, provedený v roce 1983. Při interpretaci stavebního vývoje čelního křídla hradu bylo ve shodě s D. Menclovou konstatováno, že skalní výchoz nahrazoval klasickou štítovou zed’. Zároveň však autoři průzkumu dospěli k poněkud zvláštnímu závěru, když střední část čelního křídla, založenou na skalním výchozu, interpretovali jako rozměrný podkovovitý bergfrit o průměru $14 \mathrm{~m}$, který měl spolu se západní okrouhlou věží flankovat bránu, provedenou jako tunel v čelním skalním masivu. Trojice věží s pláštovou hradbou byly přičítány původní výstavbě hradu s tím, že není důvod pláštovou zed' datovat až do doby pozdní gotiky, jak předpokládala D. Menclová (Lancinger-Muk 1983, díl II., 55-56; 1994; 90-91). Věže půdorysu ve tvaru D se v evropské hradní architektuře skutečně vyskytují, a to nejen jako hradební; dokonce tvoří svébytnou skupinu v př́ipadě hradů domácí šlechty ve Walesu, kde však jejich šiř́ka nepřesahuje 11,3 m (Brodie 2015, 232). Těmito analogiemi značně vzdálenými českému prostředí jak geograficky, tak kulturně však v této souvislosti argumentováno nebylo a autorům stavebněhistorického průzkumu zajisté slouži ke cti, že nepodlehli ani dobové mánii shledávat v předpokládaném vícevěžovém řešení vliv francouzského kastelu; uvedli pouze, že konfigurace vstupu připomíná situaci některých západních hradů (Lancinger-Muk 1983, díl II., 56). Významným zjištěním byla dále identifikace hranolové věžice na severním nároží hradu a navazujícího západního traktu řazeného do 14 . století, s nevelkými analyticky odkrytými okénky ve dvou úrovních v prvním patře, spojovaných hypoteticky s pyramidálním uspořádáním (Lancinger-Muk 1983, díl II., 57; 1994, 93).

T. Durdík (1978, 47-48) nejprve pod vlivem dosavadní literatury charakterizoval Orlík jako malý královský hrad typu blížícího se šlechtickým hradům bergfritové dispozice s tím, že je v nároží použito druhé ,flankovaci pưlkulaté věže“. Ještě ve své syntetické práci o kastelových hradech ve střední Evropě autor použil uvedený plán D. Menclové a uvedl, že se zde projevil vliv francouzského kastelového schématu (Durdík 1994, 118-120), což opakoval ve všech svých dalších pracích týkajících se počátků hradu. V Encyklopedii českých hradů vydané následujícího roku (Durdík 1995, 203-205) nejspíše pod vlivem chybně situované střední věže na plánu D. Menclové a bez znalosti dostupného zaměření hradu autor publikoval půdorys hradu se zcela deformovaným zakreslením průběhu parkánové zdi na čelní straně, jejž pak převážně používal ve svých dalších pracích. Přritom v souladu s mezitím publikovanou interpretací výsledků stavebněhistorického průzkumu uvedl, že v čele hradu byla situována mohutná polookrouhlá věžovitá stavba (Durdík 1995, 203-205). V další práci z téhož roku, kde se hradu věnoval podrobněji, sice odmítl interpretaci středního podkovovitého objektu jako věže, ale naproti tomu uvažoval o eventualitě, že jižní polookrouhlá věž je reliktem menší válcové věže, a konstatoval, že flankovací schopnost jižní věže je v důsledku tečného navázání hradby nulová (Durdík-KašičkaNechvátal 1995, 22-34). V české mutaci knihy o kastelových hradech autor tyto své názory víceméně opakoval (Durdík 1997, 122-130). Zanedlouho však T. Durdík neváhal publikovat ještě více zkomolený plán, v němž byla jím nedávno uvedená nedostatečná flankovací schopnost jižní věže „napravena“ tím způsobem, že úroveň líce navazující hradby byla posunuta poněkud dále dovnitř hradu (Durdík-Adámek-Fröhlich-Chotěbor 1998, 15). Žádné důkazy pro takové řešení autor ovšem neuvedl, a ani uvést nemohl, protože neexistují. Tato publikace se dočkala též německé mutace v souvislosti s konferencí Castrum Bene 6 (Durdík-Adámek-Fröhlich-Chotěbor 


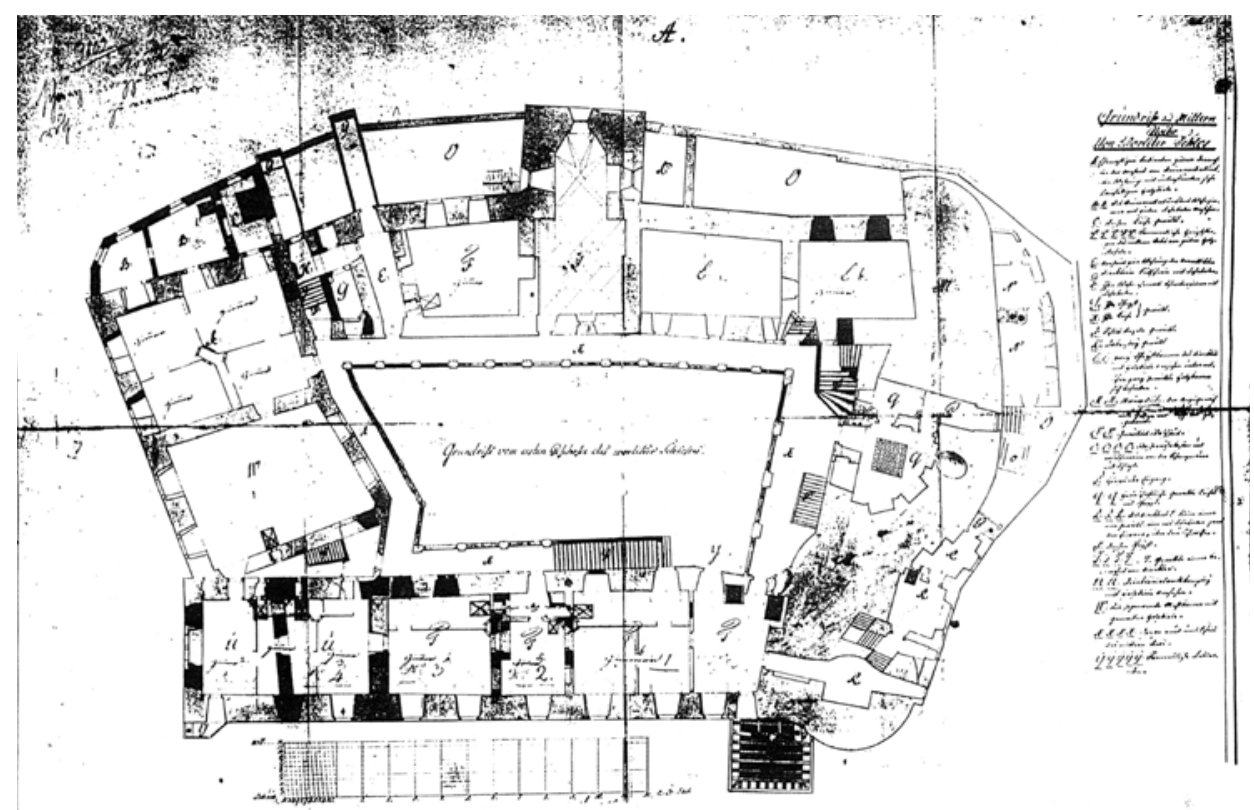

Obr. 4. Hrad Orlík, okr. Písek. Plán prvního patra hradu z roku 1802 s dobře patrným průběhem štítové zdi v čele hradu. Abb. 4. Burg Orlík, Bezirk Písek. Planskizze des ersten Stockwerks der Burg aus dem Jahr 1802 mit gut sichtbarem Verlauf der Schildmauer an der Burgfront.

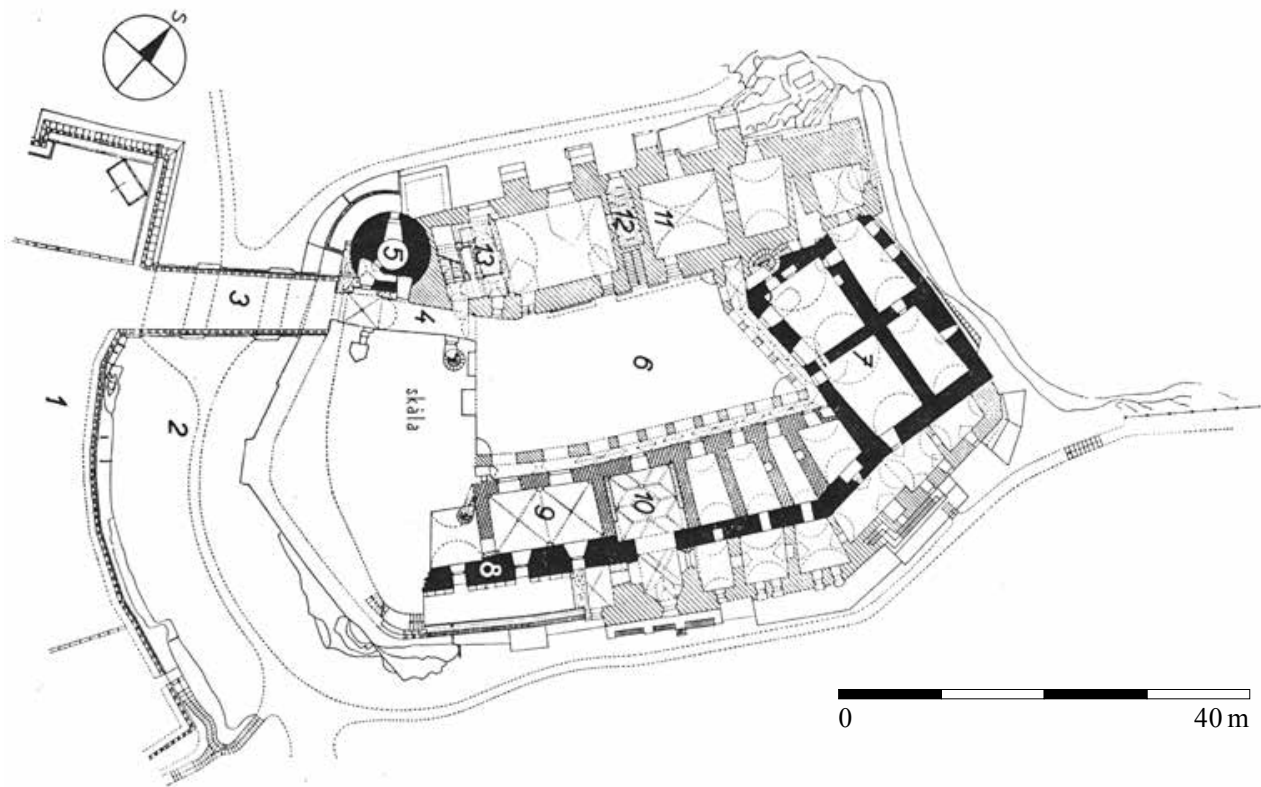

Obr. 5. Hrad Orlík, okr. Písek. Půdorys přízemí podle J. Kostky a J. Hanesche.

Abb. 5. Burg Orlík, Bezirk Písek. Grundriss des Erdgeschosses nach J. Kostka und J. Hanesch. 


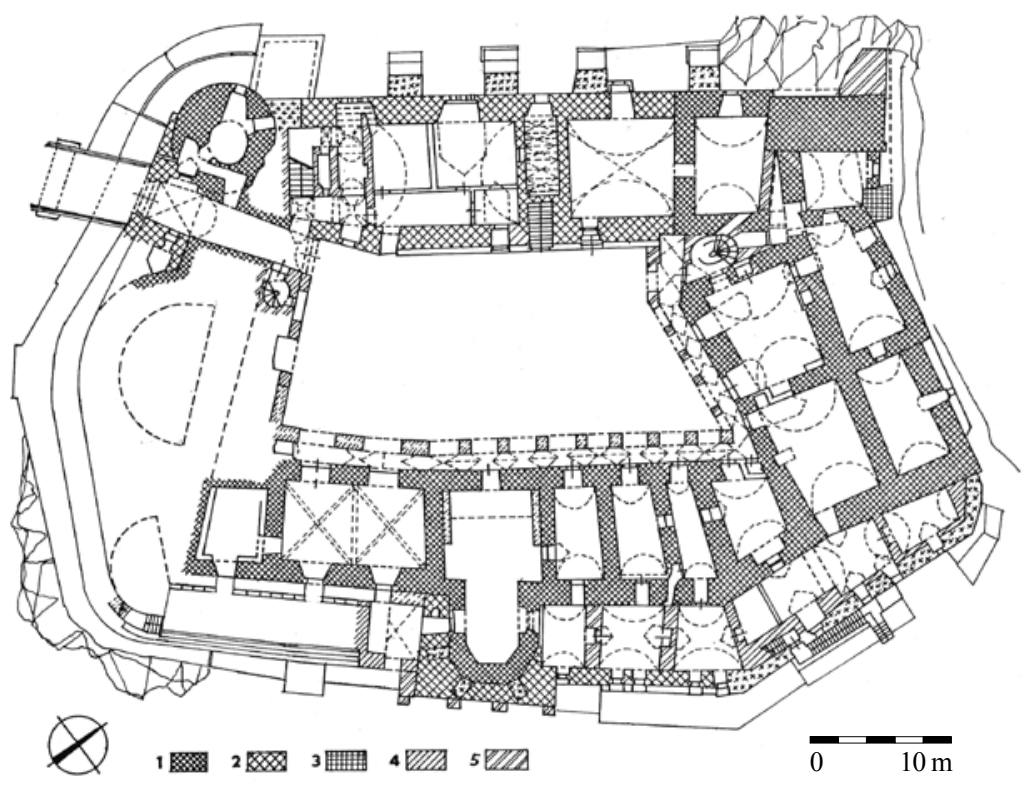

Obr. 6. Hrad Orlík, okr. Písek. Půdorys přízemí podle T. Durdíka $(1995 ; 1997 ; 1999)$ s deformovaným průběhem parkánu v čele hradu.

Abb. 6. Burg Orlík, Bezirk Písek. Grundriss des Erdgeschosses nach T. Durdík (1995; 1997; 1999) mit deformiertem Zwingerverlauf an der Burgfront.

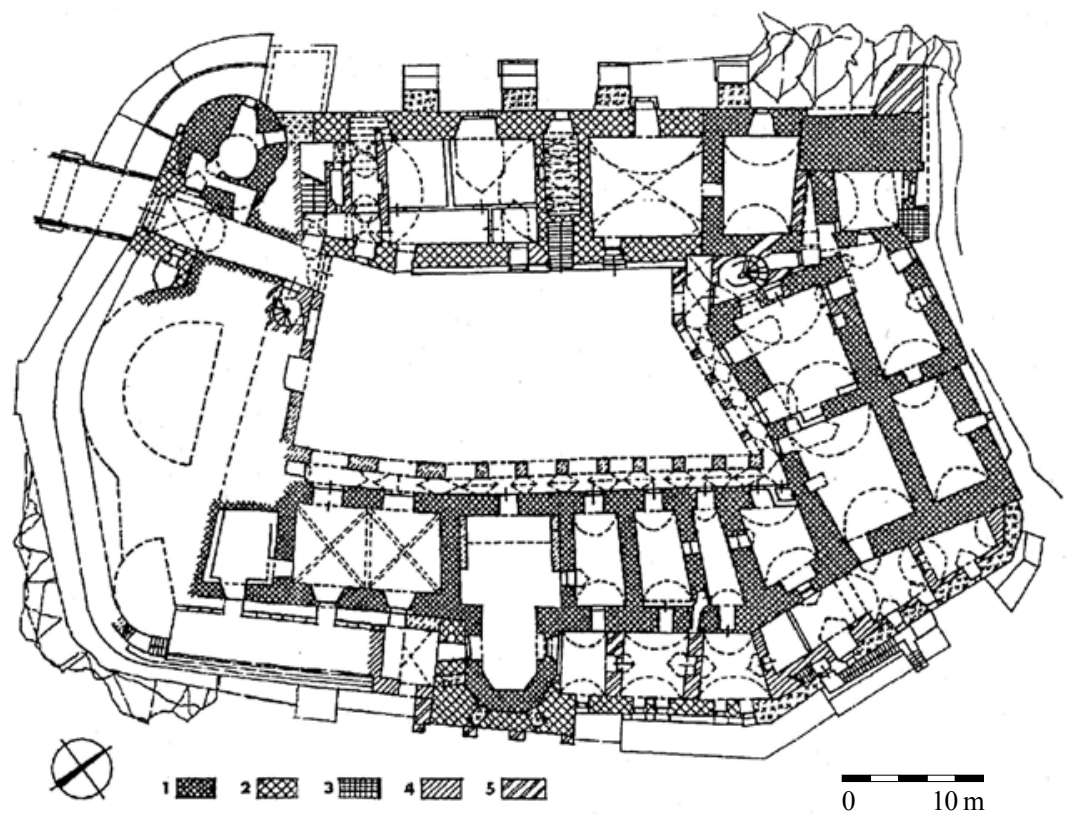

Obr. 7. Hrad Orlík, okr. Písek. Půdorys přízemí podle T. Durdíka (1998) s deformovaným průběhem parkánu a nedoloženou situací hlavní hradby v čele hradu.

Abb. 7. Burg Orlík, Bezirk Písek. Grundriss des Erdgeschosses T. Durdíka (1998) mit deformiertem Zwingerverlauf und nicht belegter Situation der Hauptwehrmauer an der Burgfront. 


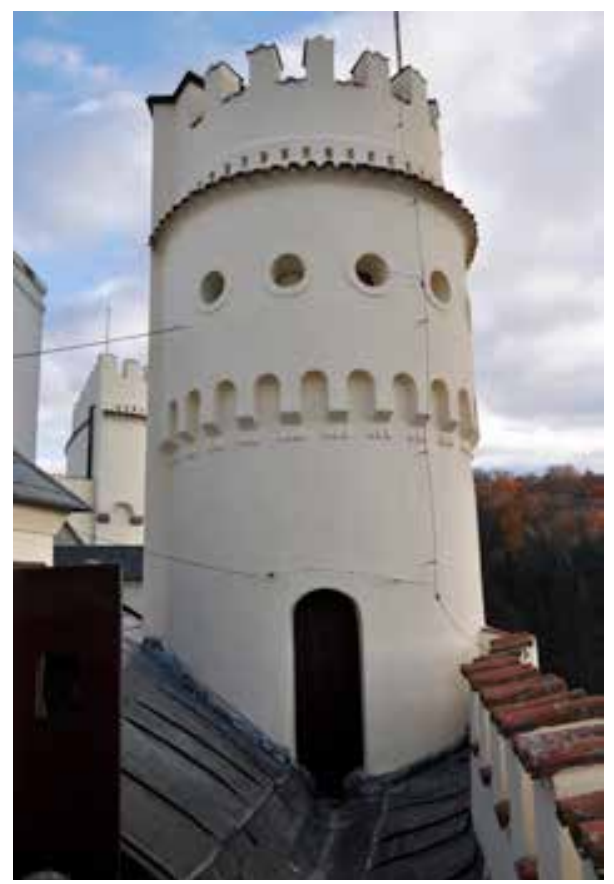

Obr. 8. Hrad Orlík, okr. Písek. Pozdně gotická střední věž z roku 1515 v klasicistní úpravě. Foto J. Varhaník, 2012. Abb. 8. Burg Orlík, Bezirk Písek. Spätgotischer Mittelturm aus dem Jahr 1515 nach klassizistischem Umbau. Foto J. Varhaník, 2012.

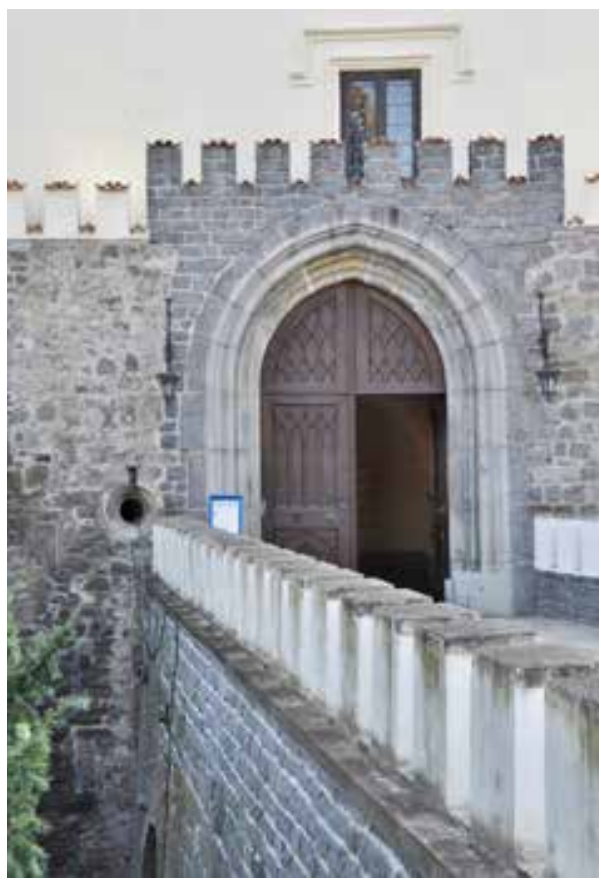

Obr. 9. Hrad Orlík, okr. Písek. Okénko z vrátnice po levé straně vstupu s novogotickou vnější úpravou. Foto J. Varhaník, 2016.

Abb. 9. Burg Orlík, Bezirk Písek. Rundöffnung der Pforte an der linken Eingangsseite mit neugotischer Außengestaltung. Foto J. Varhaník, 2016.

1998a). Ve své Ilustrované encyklopedii českých hradů autor použil svoji předchozí verzi chybného plánu hradu (Durdík 1999, 404, obr. 866), avšak tento svůj závažný omyl neopravil ani v dodatcích této své práce, ačkoli na něj bylo mezitím explicitně upozorněno (Varhaník 1998, 24, pozn. 24). Bohužel tento zkomolený plán pronikl do další literatury (Velímský 2013, 78).

Dále T. Durdík $(1995,30)$ formuloval předpoklad, že pokud by v jihovýchodním křídle vznikla kaple dodatečně, mohla se $\mathrm{v}$ jeho jihozápadní části uplatňovat sestava trojice místností, známá z hradů Přemysla Otakara II. Zjištění kvádrové armatury na západním nároží lodi kaple při dílčím odstranění omítek, dokládající, že nádvorní zed' žebrově další části tohoto traktu s žebrově klenutým sálem v přízemí byla připojena na spáru, však uvedenou hypotézu vylučuje (Varhaník 1998, 21).

Další analýza vstupního křídla hradu dospěla k závěru, že jeho stavební vývoj byl od představ dosavadní literatury zásadně odlišný (Varhaník 1998). Bylo zjištěno, že štítová zed', sahající až po hlavní římsu, probíhala až za severozápadní okrouhlou věž, s níž byla provázána. Masiv jejího zdiva zaujímal část dnešního klasicistního schodiště a prostoru nad průjezdem, pokládaným dříve za obezděný skalní výchoz. Věž, nápadně vysunutá z obvodu staršího hradu a založená hluboko ve svahu, nebyla bergfritem, ale bateriovou věží s komorovými stř́lnami, náležející novému opevnění hradu, přičítanému Zmrzlíkům ze Svojšína. Na jižním konci koruny štítové zdi vznikla věž o půdorysu kruhové výseče. Místo původní okrouhlé věže o průměru $10 \mathrm{~m}$, obklopené v nevelkém odstupu smyčkou hradby o tloušt'ce $2 \mathrm{~m}$, indikuje pravidelný kruhový segment části obvodu pozdější kuchyně v prvním patře čelního křídla na nejvyšším místě skalního výchozu, tvořený vnitřním lícem štítové zdi. Exponovaná poloha věže zřejmě vedla k jejímu zániku již při stavbě štítové zdi, nebo později v průběhu 15. století, patrně v souvislosti 
se statickými poruchami způsobenými zvětráváním skalního masivu, které stavbu trvale ohrožuje (Fuka 1978,8). Ještě vrcholné gotice náleží úzký trakt př́izemních arkád severního a jihovýchodního křídla otvírajících se do nádvoří jednoduchými hrotitými oblouky (Varhaník 2014).

Významné poznatky přinesly archeologické výzkumy hradu. Nevelký záchranný archeologický výzkum identifikoval v roce 1983 po odstranění kontreskarpy prŕíkopu nad úrovní s pravěkými nálezy vrstvu pevné hrudkovité malty, smíšené se zbytky vápna se zlomky keramiky, která byla datována do 12. století. Následující vyšší vyrovnávací vrstva s odštěpky a kusy kamene se záseky byla přičítána 13. století a spojována se stavbou jádra dnešního hradu, př́ípadně přestavbou staršího objektu (Břicháček 1989, 332-333). T. Durdík $(1995,22)$ považoval datování do 12. století za nepřesvědčivé s ohledem na malou reprezentativnost nálezového souboru a kvůli problémům $\mathrm{s}$ chronologií jihočeské středověké keramiky. Proto se přiklonil k názoru, že hrad založil Přemysl Otakar II. v závěrečné fázi své vlády.

Rozsáhlejší záchranný archeologický výzkum provedla v jižní části parkánu před jihovýchodním křídlem hradu mezi koncem štítové zdi a sakristií kaple a v klenebních zásypech pod terasou v jeho zastavěné severní části společnost Archeos v roce 1998. Výzkumem bylo zjištěno, že parkánová hradba vznikla nejpozději v polovině 14 . století a její tloušt'ka činila $1,5 \mathrm{~m}$. Okraj štítové zdi byl založen do parkánu, který byl v době její výstavby zaplněn ca $80 \mathrm{~cm}$ mocným souvrstvím, na počátku 15. století, což koresponduje se stavebněhistorickým datováním (Beneš 2000, 14-15). Žádné pozůstatky okrouhlé věže, předpokládané starší literaturou, zde zjištěny nebyly. Výkopem byl odkryt vnější líc hlavní hradby, k němuž přiléhaly cihlové vynášecí pasy na pilírích, nesoucí skarpovitou přizdívku z 16. století. Koncem 16. století byla podstatně zvýšená úroveň parkánu opatřena odvodňovací dlažbou z neopracovaných, ale pečlivě vybraných kamenů. Úroveň dlažby se svažovala k otvoru proraženému v parkánové zdi, později zaslepenému (Beneš 2000, 9).

Další záchranný archeologický výzkum proběhl na severozápadní části nádvoří v roce 2000 (Grabolle-Hrubý-Militký 2002). Podařilo se zde ověrit průběh raně gotické hradby, která je situována pod nádvorní zdí severozápadního křídla, přestože její základové spáry dosaženo nebylo. Byl zde získán početný soubor keramiky, datovaný do druhé poloviny 13. století, nebot' za hradbou se záhy začal - na poměrně strmém svahu - hromadit odpad. Nálezová situace tak dokládá vznik hradby v druhé polovině 13. století. Významné bylo zjištění, že situace severně od jejího tupoúhlého zalomení nasvědčuje místu původní brány, která byla pravděpodobně situována v místech vyústění dnešního průjezdu do nádvoří. Dále k severu byly identifikovány základy schodiště, které vedlo při průčelí severozápadního křídla do patra arkádového ochozu.

Přestože se zatím nepodařilo ve stavebním organismu hradu zjistit starší konstrukce než z druhé poloviny 13. století, není vyloučeno, že raně gotický Orlík měl staršího předchůdce, s čímž by korespondovalo také české jméno. Starší literatura uvažovala o hrádku, který střežil vltavský brod a sloužil k vybírání cla z plavby po řece (Kostka-Hanesch 1956, 1). Raně gotický hrad náležel pravděpodobně bergfritové dispozici s velkou okrouhlou věží v čele, na nejvyšším místě staveniště, obklopenou v nevelkém odstupu smyčkou obvodní hradby, která spolu s věží zprava chránila vstupní bránu.

V literatuře bylo poukázáno na okolnost, že Orlík nebyl zařazen mezi nezcizitelné statky v návrhu Karlova zákoníku, známého jako Maiestas Carolina, a že tedy od počátku šlo o objekt menšího významu, nesrovnatelný s nedalekým Zvíkovem (Durdík 1995, 23). Naproti tomu určitému nárůstu jeho významu by mohlo nasvědčovat jeho rozšiřování ve 14. století, kdy byl celý hrad obklopen parkánovou hradbou, a to i na zcela nepř́stupných místech. Vedle toho byl kladen neobyčejný důraz na obytnou složku, z níž však blíže známe pouze poměrně velký žebrově klenutý sál v př́izemí, zatímco o architektonickém ztvárnění patra není známo vůbec nic. Překvapující je však rozsah těchto obytných prostor - součet délky všech tří křídel, jejichž existenci lze pro druhou polovinu 14. století předpokládat, činí kolem $70 \mathrm{~m}$ a je tak srovnatelný s podstatně většími hrady své doby. Pravděpodobně tehdy také vznikly nádvorní arkády. Otevřená je otázka vzniku hradní kaple $\mathrm{v}$ jihovýchodním křídle s presbytářem vystupujícím do parkánu, pro jejíž existenci ve středověku nejsou žádné prřímé doklady (Záruba 2016, 145). V literatuře byly 
vysloveny úvahy, že kaple je staršího původu s odkazem na analogické řešení v Jindřichově Hradci (Lancinger-Muk 1994, 91), případně bylo poukazováno na možnost stavby kaple za významného preláta Dětřicha z Pordic (Durdík 1995, 33-34). Na základě uvedených souvislostí lze předpokládat, že význam hradu vzrostl, nebot' jeho držiteli byli významné osobnosti na dvoře Karla IV. a Václava IV.

Za Petra Zmrzlíka ze Svojšína došlo k výstavbě mohutného čelního opevnění, případné další úpravy hradu nelze vysledovat. Určité provozní, a tedy snad i stavební změny pravděpodobně signalizuje vrstva kuchyňského odpadu v parkánu s uherským zlatým dukátem Zikmunda Lucemburského, obsahující velké množství zvířecích kostí, pocházející z druhé třetiny 15 . století (Beneš 2000,11). Je zřejmé, že odpad byl do parkánu vyhazován z oken v patře jižní části jihovýchodního křídla. Je pravděpodobné, že v průběhu 15. století, kdy se Zmrzlíkové ze Svojšína aktivně zúčastňovali bojových konfrontací s katolickými protivníky, došlo k ohrazení a dalším úpravám předhradí, o jehož podobě však není nic známo, kromě poznatků ze záchranného archeologického výzkumu při přezdívání kontreskarpy př́ikopu, přičemž je zde do první poloviny 15. století datována požárová vrstva (Břicháček 1989, 332). Stopy velkého požáru z roku 1508, zjištěné v parkánu před jihovýchodním křídlem (Beneš 2000, 10), který uzavřel středověký stavební vývoj hradu, zde však kupodivu chyběly.

\section{Pozdně gotická přestavba hradu}

Kryštof ze Švamberka koupil vyhořelý a opuštěný hrad roku 1514 (Sedláček 1936, 62). Následující poměrně rozsáhlé úpravy jsou částečně dokumentovány písemnými prameny, přičemž podobu hradu po přestavbách 16. století již zachycuje historická ikonografie z doby před požárem v roce 1802, nebot' barokní úpravy změnily jeho vnější vzezření jen poměrně málo. Jde zejména o rytinu W. Bergera podle kresby F. K. Wolfa z roku 1787 od severu a kolorovaný lept K. Postla a L. Janschy z doby kolem roku 1800. Poněkud nižší vypovídací hodnotu má kopie obrazu A. Kafendy, pozoruhodná však tím, že se neomezuje na samotný hrad, ale zabírá též rozsáhlou a členitou zástavbu předhradí, stejně jako vyobrazení stavu hradu a předhradí od J. J. Planskera, které rekonstruuje stav k roku 1737. Nejvěrnější je zjevně veduta W. Bergera a F. K. Wolfa zachycující hrad od severozápadu, naproti tomu kolorovaný lept K. Postla a L. Janschy sice obsahuje cenné detaily, avšak střechy věží jsou romanticky převýšeny a skutečnosti neodpovídá ani větší počet opěráků severozápadního křídla.

Špatný stav hradu opuštěného po požáru je konstatován v dopise Jindřicha ze Švamberka jeho synovci Kryštofovi z 12. dubna 1513, pojednávajícím o připravované transakci. Výslovně se v něm uvádí, „že se zdi po tom shoření velmi valejí a padaji“ (AČ XV, 96 č. 182), což dokládá horní část jedné $\mathrm{z}$ prríčných zdí v jediné stavebně podstatně neupravované místnosti v severní části přízemí jihovýchodního křídla, kde je patrné navázání dosti ledabyle kladených nízkých cihel na starší porušené lomové zdivo. $Z$ této nálezové situace lze dovozovat, že úzké prostory v př́izemí byly původně plochostropé a $\mathrm{k}$ jejich zaklenutí došlo až v rámci pozdně gotické přestavby.

Zpráva z konce září roku 1515 zmiňuje zřizování vápenice, dokončování krovu na plášti a záměr stavby třetí věže „,na prostřed pláště“ (AČ XV, 116 č. 206). Vyplývá z ní, že věžovitá nástavba na jižním zaobleném konci štítové zdi již tehdy existovala. Podoba zastřešení čelního kř́ídla se v historické ikonografii liší; nejspolehlivější vyobrazení (Berger-Wolf) zde zachycuje vysokou střechu kónického tvaru s makovicí na vrcholu, z jejíž spodní části vyrůstá střední vížka. Na obou relativně schematických vyobrazeních hradu s předhradím je ochoz na vrcholu štítové zdi kryt jen poměrně nízkou střechou.

Další zprávy písemných pramenů o stavební činnosti v letech 1515-1520 shromáždil L. Lancinger (Lancinger-Muk 1983, díl I., 3-6). V roce 1516 byly do velké hloubky zakládány pilíře, které lze ztotožnit s mohutnými opěráky severozápadního křídla, uvádí se dokončování klenby čelední světnice, lokalizovat ji však činí potíže, dále pak dokončení „pokojů nad 
mostnici" s výjimkou jejich dlažby. V témže roce došlo k pokrytí všech tří věží. V roce 1519 se připravovalo osazování dřevěných stropů a pracovalo se na světnici nad řekou.

Parkánová zed' nad příkopem byla opatřena klíčovými stř́ílnami. Zřejmě úplnou novostavbou byl nevelký trakt, který zaujal část parkánu před branou ve štítové zdi. Pro rekonstrukci předchozího stavu této části hradu nejsou k dispozici žádné doklady, lze se pouze podle analogií domnívat, že se jedna brána, opatřená padacím mostem, otvírala v parkánové zdi, a za ní další byla v úrovni vnějšího líce štítové zdi, která v těchto místech dosahovala značné tloušt'ky (Varhaník 1998, 22-23). Nová budova obsahovala již jen jedinou bránu, která ústila do prostoru sklenutého křížovou klenbou bez žeber, dosahující větší výšky než následující valená klenba průjezdu do nádvoří. Na levé straně byla zřízena vrátnice, zčásti vylámaná ve zdivu bateriové věže a propojená s jejím interiérem. Z ní hleděl otvor neobvyklého kruhového průřezu, na vnějším líci zdiva upravený novogoticky do podoby klíčové stř́ilny, umožňující sledovat příchozí. V jeho spodní části je doposud patrný negativ trámku sloužícího jako opora hákovnice. Uvedený prostor byl později využíván různě, podle A. Sedláčka $(1936,58)$ jako vězení, v 19. století v něm byl byt zámeckého podomka. Trakt, krytý pultovou střechou a přiléhající ke štítové zdi, je zachycen na plánu hradu z roku 1802, brzy nato byl však zbořen.

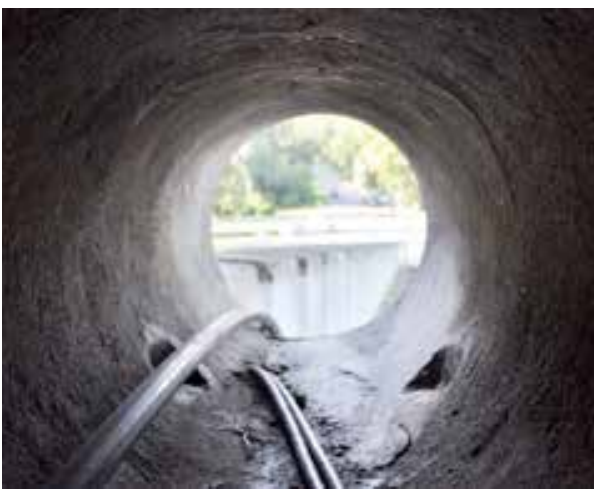

Obr. 10. Hrad Orlík, okr. Písek. Okénko z prostoru vrátnice s otisky po trámku pro zapření hákovnice. Foto J. Varhaník, 2016.

Abb. 10. Burg Orlík, Bezirk Písek. Aus der Pforte führende Rundöffnung mit Abdrücken eines Balkens als Stütze für eine Hakenbüchse. Foto J. Varhaník, 2016.

Dílem této přestavby snad mohlo být vyložené podstř̌š̌ní patro na odstupněné nižší části štítové zdi, vystupující za bateriovou věží z obrysu hradu. Podle historické ikonografie mělo bedněné (Berger-Wolf) či hrázděné (Janscha-Postl) stěny. Kryté bylo nízkou stanovou střechou.

Největší novostavbou bylo velkoryse rozvržené křídlo mezi zadním lícem štítové zdi za bateriovou věží a starší budovou na severu. Jeho nádvorní zed' byla založena na hradbě z 13. století, jejíž průběh zde byl ověřen archeologickým výzkumem, zatímco pro vnější zed' byla pravděpodobně částečně využita parkánová hradba. Př́ípadná starší zástavba v parkánu, pokud zde existovala, zřejmě v důsledku výstavby tohoto kř́dla zanikla beze zbytku.

Na vnějším průčelí je analyticky odkryta část okenního ostění prvního patra nedaleko zmíněné nižší části štítové zdi, opatřené novodobým cimbuřím. Dvojice velkých oken v přízemí je výsledkem novodobé rekonstrukce, pravděpodobně na místě původních. Další analyticky přiznané detaily se uplatňují až dále k severovýchodu. Jde o trojici shodných, na hraně okosených ostění nevelkých okének, z nichž první zprava je přibližně situováno těsně nad úrovní parapetu dnešních oken, zatímco další dvě leží podstatně výše. Jejich vzájemná poloha neodpovídá pyramidální sestavě menších okének, jimiž se vyznačovaly místnosti s vloženými sruby, nebot' rozestup obou horních okének je podstatně menší středního a spodního vpravo. Zatímco obě horní okénka již náleží staršímu objektu na severním nároží, k němuž bylo severozápadní křídlo organicky připojeno, poloha spodního okénka odpovídá přibližně úrovni jihozápadního líce prŕččné zdi, které jej od novostavby severozápadního křídla odděluje. Bud' tedy bylo starší křídlo ještě delší, než usuzoval J. Muk (Lanciger-Muk 1994, 91, obr. 4), nebo, což je pravděpodobnější, okénka náleží až pozdně gotické přestavbě. Snad mohla osvětlovat schodiště v tloušt'ce zdiva vyrovnávající výškové rozdíly mezi starším objektem a novostavbou. Pochybnosti vzbuzuje původnost drobného arkýře s okénkem při druhém opěráku od severu, nebot' na relativně důvěryhodném vyobrazení (Berger-Wolf) chybí. Na dvorním průčelí se uplatňuje trojice pravoúhlých portálků s plochou profilací s drobnými přetínajícími se oblounky přízemí, které však J. Muk 


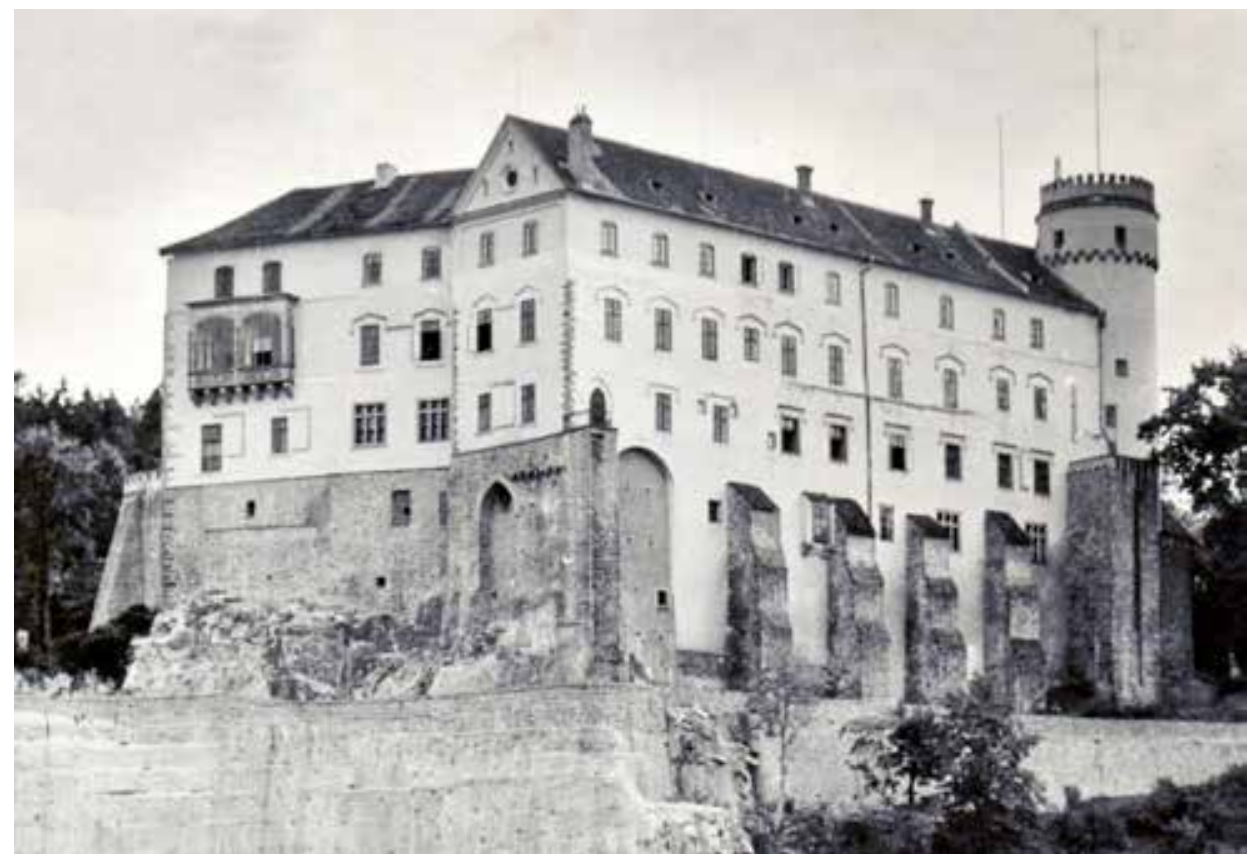

Obr. 11. Hrad Orlík, okr. Písek. Pohled od severu po provedení statického zajištění skalního ostrohu z roku 1961. Abb. 11. Burg Orlík, Bezirk Písek. Blick aus Norden nach erfolgter statischer Sicherung des Felssporns im Jahr 1961.

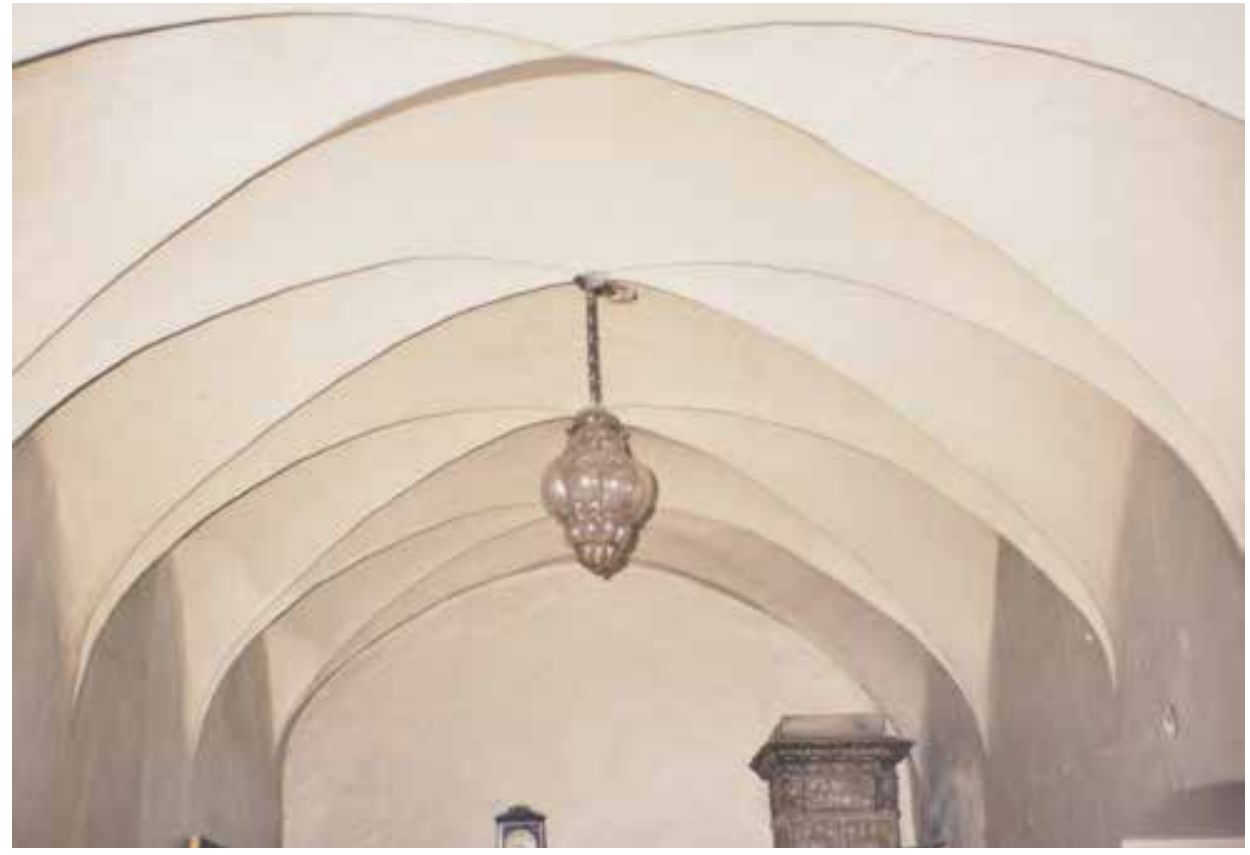

Obr. 12. Hrad Orlík, okr. Písek. Jednoduchá sklípková klenba v přízemí severozápadního křídla. Foto J. Varhaník, 1997. Abb. 12. Burg Orlík, Bezirk Písek. Einfaches Zellengewölbe im Erdgeschoss des Nordwestflügels. Foto J. Varhaník, 1997. 

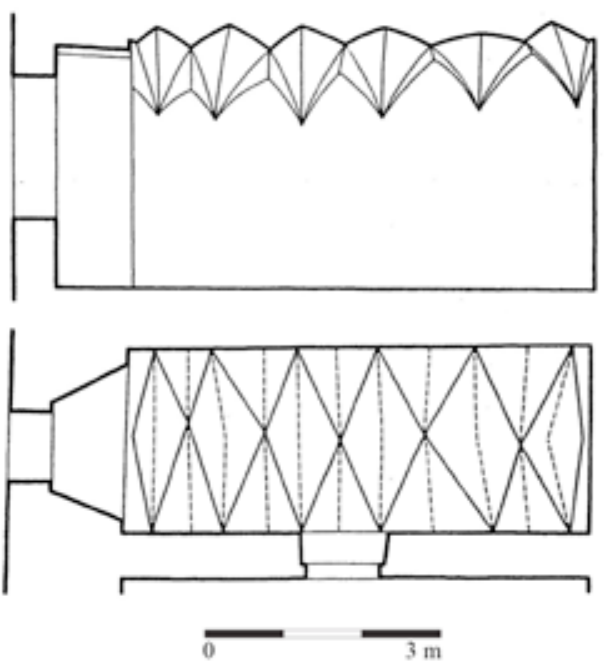

Obr. 13. Hrad Orlík, okr. Písek. Podélný řez místností se sklípkovou klenbou. Podle Radovi 1998.

Abb. 13. Burg Orlík, Bezirk Písek. Längsschnitt durch den Raum mit Zellengewölbe. Nach Radovi 1998. považoval za dílo 19. století (Lancinger-Muk 1983, díl II., 12), v úrovni prvního patra na pavláčce, podpírané kamennými krakorci, pak další dva portálky tohoto typu a mezi nimi analyticky přiznaná část ostění velkého trojdílného pravoúhlého okna s drobnou přetínavou profilací a stopami příčníku. Vyskytl se názor, že ostění pravoúhlých portálků byla tesána kameníky ze současných staveb v Bechyni a dopravována po Lužnici a Vltavě na Orlík (Radovi 1998, 192).

Valeně zaklenuté sklepy byly přístupné z nádvoří schodištěm situovaným přibližně uprostřred dvorního průčelí. Na tuto stranu byly také odvětrávány nevelkými okénky. Valenými klenbami bylo opatřeno také prrízemí $\mathrm{s}$ výjimkou prostoru nad schodištěm do sklepů, který byl využit pro nevelkou podlouhlou místnost opatřenou sklípkovou klenbou. Její vzorec je však podstatně jednodušší než na ostatních sasky orientovaných stavbách, a to

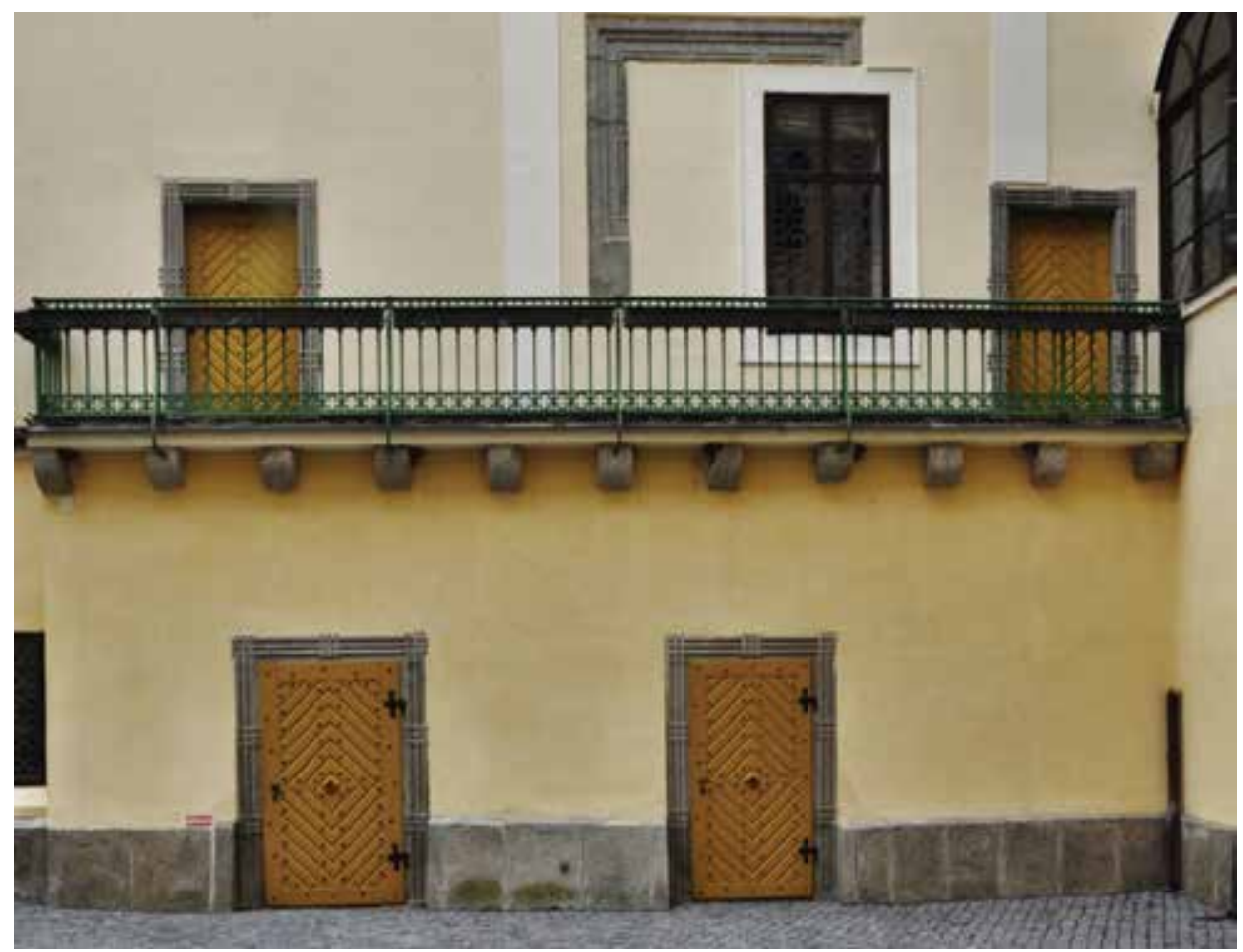

Obr. 14. Hrad Orlík, okr. Písek. Nádvorní průčelí severozápadního křídla s pozdně gotickými portálky a analyticky přiznaným ostěním okna. Foto J. Varhaník, 2017.

Abb. 14. Burg Orlík, Bezirk Písek. Hoffassade des Nordwestflügels mit kleinen spätgotischen Portalen und analytisch anerkannten Fensterlaibungen. Foto J. Varhaník, 2017. 


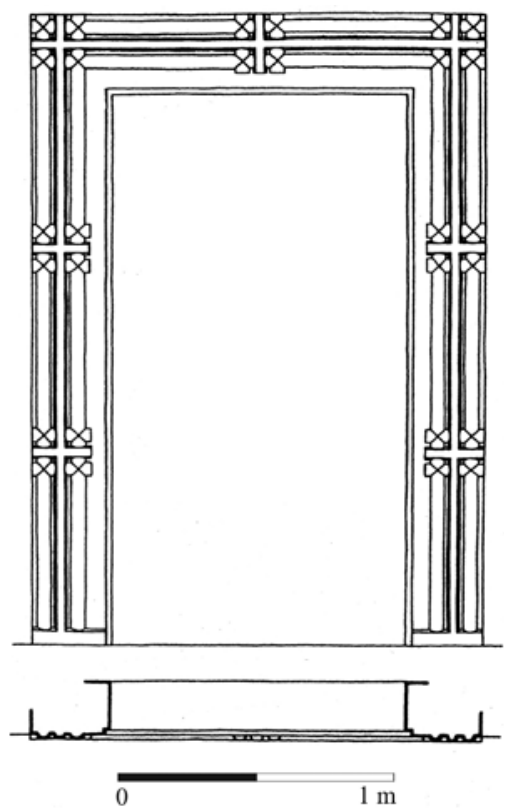

Obr. 15. Hrad Orlík, okr. Písek. Pozdně gotický portálek s plochou přetínavou profilací. Podle Radovi 1998.

Abb. 15. Burg Orlík, Bezirk Písek. Kleines spätgotisches Portal mit flacher überstabender Profilierung. Nach Radovi 1998.

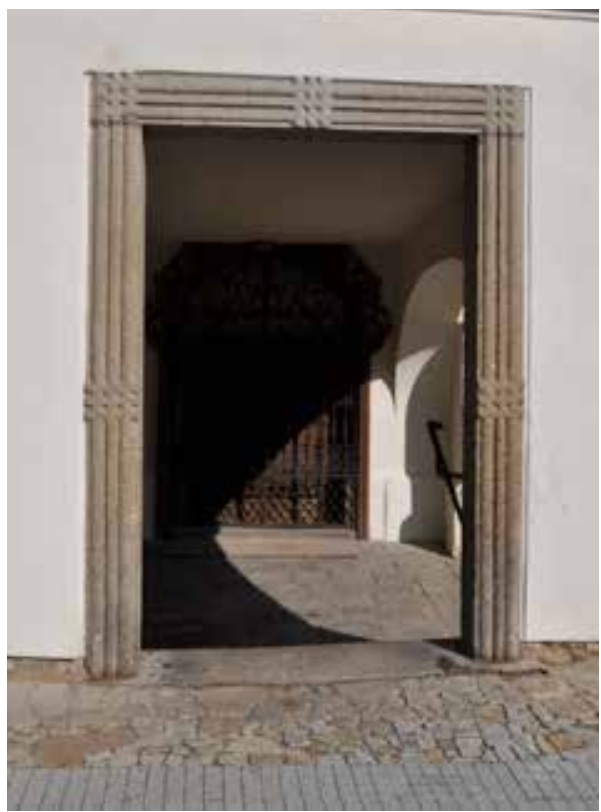

Obr. 16. Bechyně, okr. Tábor. Portálek předsíně kostela františkánského kláštera. Foto J. Varhaník, 2017.

Abb. 16. Bechyně, Kreis Tábor. Kleines Portal des Vorraums der Franziskanerklosterkirche. Foto J. Varhaník, 2017.

jak budovaných Švamberky - hradu v Boru u Tachova a v kapli v Horní tvrzi v Kestřanech, tak jinými stavebníky v nedaleké Blatné a Bechyni. $Z$ toho by bylo možné dovozovat, že šlo o práci jednoho z jihočeských zedníků, který participoval na některé z uvedených staveb a na Orlíku pak podle nabytých zkušeností provedl poněkud jednodušší variantu sklípkové klenby. Jejímu poněkud rustikálnímu provedení ostatně odpovídá nejednotná výška výběhů a nestejně velká klenební pole (Radovi 1998, 192). V sousední místnosti se v př́ičné zdi dochoval zazděný zamřižovaný portálek $\mathrm{s}$ jednoduše okoseným ostěním a $\mathrm{s}$ užším, původně též zamřížovaným nadsvětlíkem. Jeho účel není zcela jasný. Část profilovaného ostění je analyticky přiznána také $\mathrm{v}$ prríčné zdi prvního patra.

V dalších křídlech došlo $\mathrm{k}$ radikální přestavbě prvního patra, místy dokonce i přízemí, jak to dokládají klenby z nízkých cihel v jihovýchodním křídle. Jediným svědectvím zůstávají analyticky přiznaná ostění oken na vnějších průčelích.

Plocha nádvoří byla vydlážděna valounovou dlažbou (Grabolle-Hrubý-Militký 2002, 93). Velice pozoruhodnou úpravu představuje rozšíření pilířủ nádvorních arkád jihovýchodního křídla, provedené z cihel formátu $27 \times 13,5 \times 6 \mathrm{~cm}$, z něhož lze důvodně dovozovat, že jejich dosavadní, snad jen dřevěné patro bylo nově provedeno náročnějším způsobem (Varhaník 2014, 28). Patro arkád bylo přístupné schodištěm při dvorním průčelí severozápadního křídla, jehož starší fáze náležela snad ještě vrcholně gotické výstavbě, nebot' předcházelo položení uvedené valounové dlažby (Grabolle-Hrubý-Militký 2002, 95).

Nejpozději v této době byla zastavěna část parkánu na severovýchodní straně a další trakt patrně vznikl v severní části parkánu před jihovýchodním kř́ílem. Na základě jednotně provedené kvádrové armatury severovýchodního nároží, stoupající až do druhého patra, předpokládal J. Muk, že zde druhé patro vzniklo již za pozdně gotické přestavby, stejně jako v jihovýchodním křídle (Lancinger-Muk 1983, díl II., 58-59). Za současného stavu poznání však jsou hlavním 
vodítkem analyticky prezentovaná kamenná ostění oken, která se ovšem v úrovni druhého patra s výjimkou rizalitu nad presbytářem kaple neuplatňují.

Prakticky veškerá literatura týkající se hradu se shoduje $\mathrm{v}$ tom, že dílem pozdně gotické přestavby hradu byla též kaple, avšak liší se $\mathrm{v}$ názorech na poměrně obtížně řešitelnou otázku, zda byla $\mathrm{v}$ jihovýchodním křídle zřízena zcela nově, či zda šlo o úpravu starší kaple, pocházející ještě ze 14. století. Její lod' zaujímá přibližně obdélný prostor jihovýchodního křídla, na který navazuje presbytář s polygonálním závěrem, vloženým do hranolového rizalitu, jenž vystupuje až do úrovně parkánové zdi. Nejnověji se kaplí zabýval F. Záruba (2016, 145-151), který dospěl k závěru, že kaple vznikla až v pozdní gotice a může souviset $\mathrm{s}$ podobně utvářenou kaplí v Boru u Tachova, což poněkud zjednodušeně odůvodnil tím, že nápadné zesílení zdiva rizalitu na jihozápadní straně je takto dimenzováno s ohledem na možné ostřelování, a souvisí tak s opevněním pozdně gotického průčelí hradu se dvěma věžemi. Jak bylo výše uvedeno, štítová zed' v čele hradu však vznikla podstatně dříve, s největší pravděpodobností již v druhém desetiletí 15. století (Varhaník 1998;

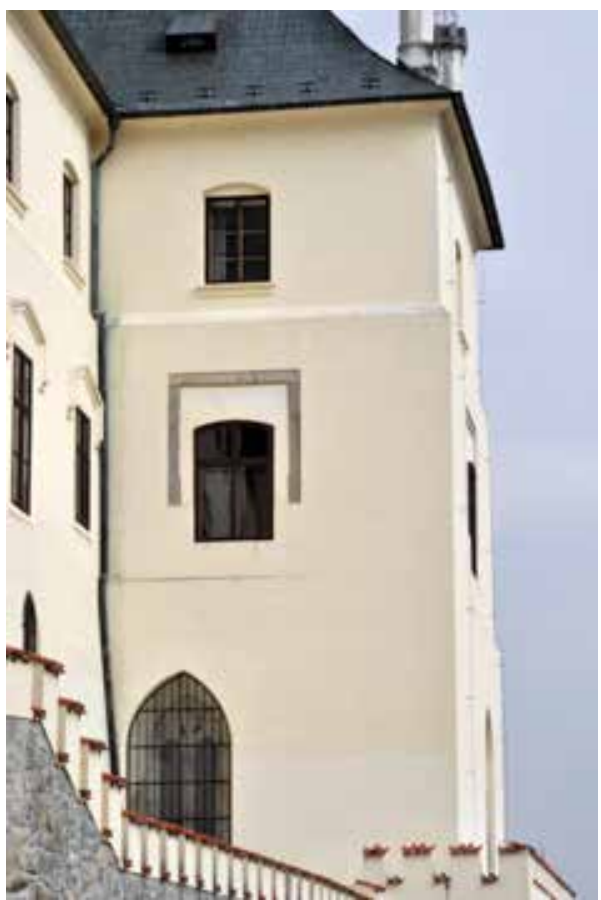

Obr. 17. Hrad Orlík, okr. Písek. Rizalit obsahující presbytář kaple. Foto J. Varhaník, 1997.

Abb. 17. Burg Orlík, Bezirk Písek. Den Altarraum der Kapelle enthaltender Risalit. Foto J. Varhaník, 1997. 2002, 132), a nelze ji tedy spojovat s poz-

dně gotickou přestavbou hradu, která proběhla o století později. Pokud by mělo zesílené zdivo rizalitu být současné s opevněním hradu na čelní straně, což nelze vyloučit, naopak by to znamenalo, že v době výstavby štítové zdi již kaple existovala a došlo k obezdění jejího presbytáře. Této eventualitě nasvědčuje skutečnost, že se v druhém patře na rizalitu nad presbytářem kaple uplatňují stejná analyticky prezentovaná ostění pravoúhlých oken jako jinde v prvním patře, přičemž na průčelích rizalitu probíhá mezi oběma patry nápadný ústupek. Je tedy pravděpodobné, že již obezděný presbytář kaple byl při první švamberské přestavbě zvýšen o druhé patro a nabyl tak věžového charakteru, který zdůrazňovala vysoká stanová střecha se sanktusníkem, patrná na kopii Kafendova obrazu. Kružby s jednoduchými plaménkovými motivy jsou provedeny poměrně hrubě, nicméně náleží až úpravám z druhého desetiletí 16. století, s čímž koresponduje formát cihel užitých ve vnějších špaletách oken. Při částečném odstranění omítek v roce 1998 bylo zjištěno, že v nárožích rizalitu se uplatňují pouze dva armovací kvádry na jižním z nich, jinak jsou vyzděna z lomového kamene. Pozoruhodným nálezem byl nevelký úsek $36 \mathrm{~cm}$ širokého omítkového rámu severního okna kaple, který se zachoval pod úrovní rozebrané dlažby terasy. Šambrána byla tvořena jednou vrstvou omítky s hrudkami vápna. Její povrch byl uhlazen dřevěným hladítkem a opatřen okrově zbarveným, mírně narůžovělým nátěrem. Z tohoto ojedinělého nálezu lze usuzovat na vnější úpravu průčelí při této přestavbě hradu, charakteristickou pro architekturu pozdní gotiky, zatímco další stopy takovéhoto výtvarného řešení vzaly za své nejpozději při odstraňování omítek bez odborné dokumentace na počátku 90. let minulého století, pokud se tak nestalo již při některé z dřívějších oprav.

Interiér kaple, nedostatečně osvětlený jedním oknem nad kruchtou a trojicí dalších v závěru presbytáře, se dochoval v novogotické úpravě, při níž došlo k určitým stavebním zásahům, které znemožňují posouzení předchozího stavu. Klenby pocházejí pravděpodobně až z 19. století, 


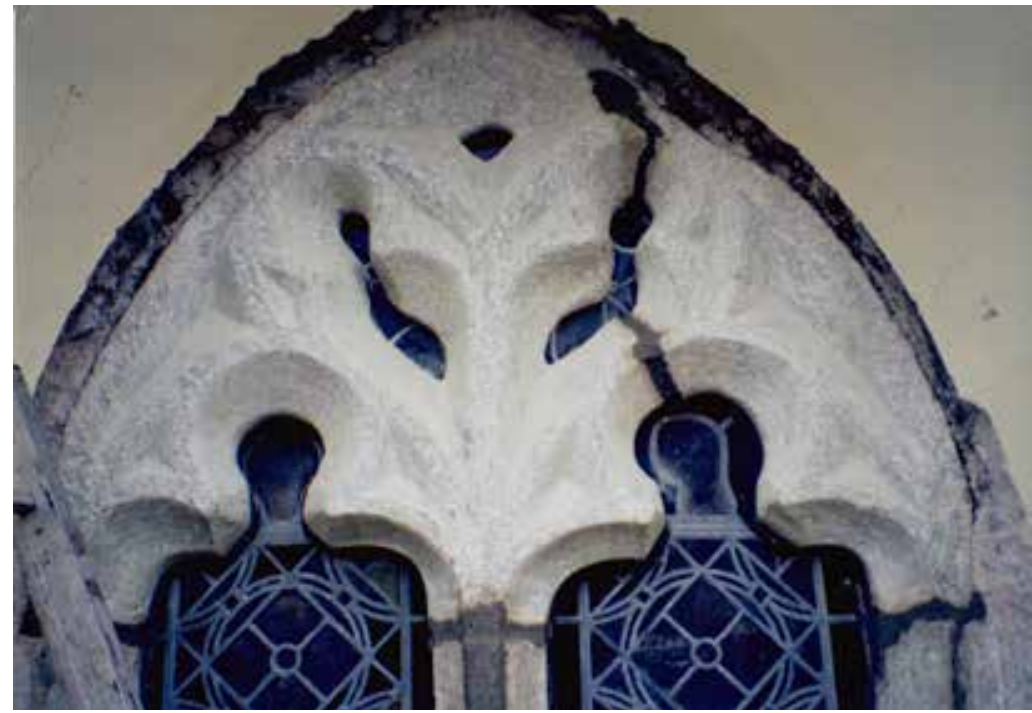

Obr. 18. Hrad Orlík, okr. Písek. Kružba stř̌edního okna presbytáře kaple. Foto J. Varhaník, 1998. Abb. 18. Burg Orlík, Bezirk Písek. Maßwerk des Mittelfensters des Altarraums der Kapelle. Foto J. Varhaník, 1998.

avšak jejich vzorec odpovídá plánu z roku 1802. Neobvykle utvářená špaleta jihozápadního okna by mohla nasvědčovat složitějšímu stavebnímu vývoji, odpovídajícímu dodatečnému obezdění presbytáře. V rámci novogotické úpravy byla zřízena také přizdívka na jeho vnitřní straně (Lancinger-Muk 1983, díl I., 27).

Obtížně řešitelná je otázka vzniku dvojice ústupků, jimiž se spodní část lodi před neprofilovaným hrotitým triumfálním obloukem mírně rozšiřuje. Nejde o úpravy související se zřízením novogotické kruchty, nebot' je zachycuje již plán hradu z roku 1802. V analytických plánech byly v literatuře vyhodnoceny rủzně, naposled je F. Záruba $(2016,15$, obr. 124) přiřknul staršímu gotickému zdivu, ačkoli předpokládal vznik kaple až v pozdní gotice. Podobné utváření východní části lodi není v této době neobvyklé. Poměrně mělké, segmentově zaklenuté niky se uplatňují v lodi hradního kostela v Rabí (Záruba 2016, 118), kde je zřejmé, že souvisely s dvojicí bočních oltářro , jejichž menzy se zde zachovaly. Obdobné, avšak podstatně vyšší niky po stranách triumfálního oblouku jsou v kapli v Boru u Tachova, podle F. Záruby blíže neznámého určení (2016, 142). Menzy oltáŕů zde chybí a je otázka, zda zde původně byly. Zcela mělké, rovněž segmentově završené niky člení jižní stěnu stísněného prostoru kaple se sklípkovou klenbou v horní tvrzi v Kestřanech (Záruba 2016, 192-196) pocházející ze švamberské přestavby, současné s pracemi na Orlíku. Ve velice úzkém interiéru kestřanské kaple ovšem sotva přicházely boční oltáře v úvahu. V prŕípadě orlické kaple za současného stavu poznání nelze než nechat otázku původu těchto prvků otevřenou.

Pozdně gotické přestavbě je $\mathrm{v}$ literatuře přičítána také kuchyně ve střední části čelního kř́ídla za štítovou zdí. Vzhledem k poloze na skalním výchozu byla situována až v úrovni prvního patra. Její neobvyklý čtvrtkruhový půdorys byl determinován předchozím poměrně složitým stavebním vývojem této části hradu. Kruhový segment zde indikuje negativ obvodu zaniklé okrouhlé věže, již na této straně obíhala v nevelkém odstupu smyčka hradby. Při výstavbě štítové zdi byla tato soutka vyplněna přizdívkou a věž byla již tehdy, nebo brzy poté odstraněna. Spáru mezi původní hradbou a touto přizdívkou názorně dokládají praskliny v sousedním průchodu do parkánu, způsobené dilatací různě starých částí štítové zdi. Dýmník kuchyně patrně spočíval na 
pilírích přistavěných k jejímu obvodu, navzájem spojených segmentovými pasy. Po odstranění dýmníku byl prostor kuchyně zaklenut na dvojici na sebe kolmo situovaných pasů, mezi nimiž se uplatňují úseky segmentových kleneb. Plán z roku 1802 zachycuje ještě pec, zahloubenou do štítové zdi. Kuchyně postrádá architektonické články a její interiér je omítnut. Velice pozoruhodná je okolnost, že přizdívka připojená $\mathrm{k}$ vnitřnímu líci štítové zdi pro střední věž z roku 1515 je zčásti situována nad okrajem prostoru kuchyně, nebot' tloušt'ka zdiva $\mathrm{v}$ úrovni druhého a třetího patra $\mathrm{v}$ těchto místech činí 4,6 m, zatímco v prvním patře v úrovni kuchyně ,jen“ $3,6 \mathrm{~m}$. Toto staticky nepř́liš vhodné řešení zřejmě vyvolalo určité pochybnosti, jak uvádí ve svém dopise pánovi hradu jeho purkrabí Jiřík z Adlaru „,...) i zdá se Michalovi tesaři, že nebude to věc stálá (...)“ (AČ XV, 116 č. 206). Je překvapující, že se tesař vyjadřoval k problematice, která se bezprostředně netýkala jeho vlastního řemesla, ale patrně šlo o zkušeného a respektovaného člověka, jehož mínění purkrabí považoval za důležité. Přes tyto zajisté oprávněné pochyby však byl původní záměr realizován; přizdívka zřejmě spočívá na pasech pro dýmník. Kuchyně tedy musela při stavbě prostř̌ední věže již existovat (Varhaník 1998, 21, pozn. 34), ovšem důkazy pro její bližší datování k dispozici nejsou. Výše zmíněný nález vrstvy kuchyňského odpadu v jižní části parkánu z druhé třetiny 15 . století (Beneš 2000 , 11) by mohl nasvědčovat tomu, že kuchyně tehdy nebyla př́liš daleko, a není tedy vyloučeno, že již tehdy zaujala místo odstraněné velké věže.

Kryštof(I.) ze Švamberka se v roce 1519 zúčastnil jako jeden ze zástupců nezletilého krále Ludvíka volby Karla V. za římského krále ve Frankfurtu nad Mohanem. V této souvislosti byl vysloven předpoklad, že pro něho byla tato účast výnosná, což bylo spojováno mimo jiné právě s přestavbou Orlíka (Jánský 2006, 296). Kryštof náležel mezi nejbohatší př́íslušníky panského stavu Českého království. Podle berního rejstříku z roku 1529 zaujal čtvrté místo po Vojtěchovi z Pernštejna, rožmberském vladaři Janu Strakonickém a nejvyšším purkrabí Zdeňku Lvu z Rožmitálu (Jánský 2006, 305). Kryštof zemřel počátkem roku 1534 na Krasíkově a byl pohřben v bechyňském klášteře, kde je dochován jeho náhrobek. Orlík obdržela jeho manželka Anežka Bezdružická z Kolovrat († 1538) jako své vdovské sídlo (Jánský 2006, 309).

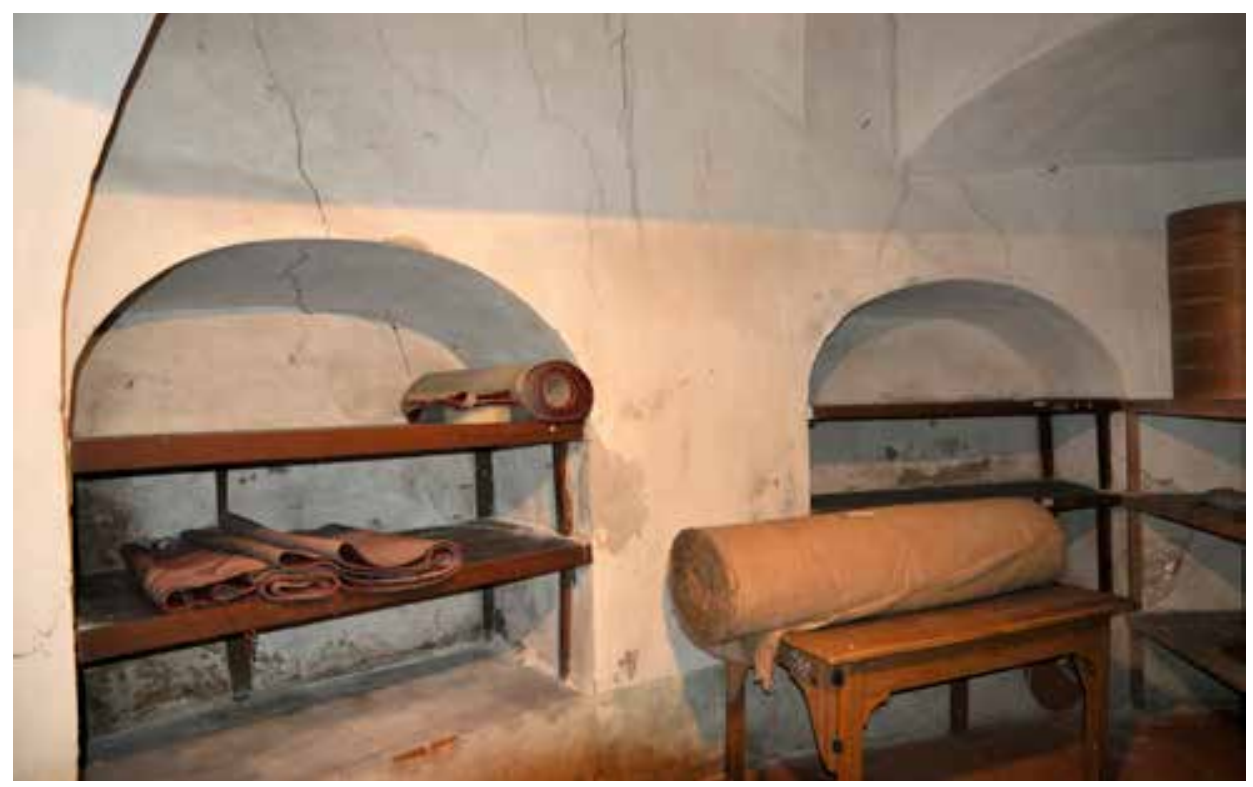

Obr. 19. Hrad Orlík, okr. Písek. Interiér někdejší kuchyně v prvním patře čelního křídla. Foto J. Varhaník, 2012. Abb. 19. Burg Orlík, Bezirk Písek. Innenraum der ehemaligen Küche im ersten Stock des vorderen Flügels. Foto J. Varhaník, 2012. 


\section{Renesanční přestavba hradu}

Při dělení majetku zvíkovské větve švamberského rodu připadl Orlík Kryštofovu synovi Bohuslavovi († 1552). Za něho došlo v roce $1550 \mathrm{k}$ úpravám vrcholu západní věže - uvádí se bourání hlásnice, přestavba světnice staré hlásnice a latování krovu na ní (Lancinger-Muk 1983, díl I., 6). Jde zřejmě o projev dobového trendu zřizování obydlí pro hlásné, k jakému tehdy došlo také na nedalekém Zvíkově, kde byla dochovaná světnička pro hlásného vybudována $\mathrm{v}$ rámci zvyšování zdiva břitové věže v roce 1554 (Sedláček 1936, 7).

Kryštof (II.) ze Švamberka získal roku 1569 orlické panství, zatížené dluhy po Johance Berkové z Lobkovic, vdově po Bohuslavovi, od svého strýce Jindřicha, po němž v roce 1574 zdědil Zvíkov a Kestřany (Jánský 2006, 349).

V letech 1577-1579 je doložena výmalba interiérů táborským malířem Ludvíkem Oberdorferem (Thir 1920, 496). Snad již tehdy byla zahájena renesanční přestavba, při níž byly do té doby převážně jen jednopatrové budovy hradu zvýšeny o další patro. Analyticky přiznaná armatura nároží druhého patra severozápadního křídla je patrná za bateriovou věží.

J. Muk podle detailů na vyobrazení hradu před požárem v roce 1802 (Janscha-Postl) dospěl k závěru, že severozápadní křídlo bylo opatřeno lunetovou římsou (Lancinger-Muk 1983, díl II., 60). Takové řešení by sice bylo v souladu s projevy tehdejší renesanční architektury v Čechách, závažné pochybnosti o této interpretaci však vzbuzuje realističtější a o několik let starší pohled na hrad (Berger-Wolf), který takovouto římsu nezachycuje, stejně jako prevét, který ji na předchozím vyobrazení na severozápadním průčelí přerušuje.

Renesančního původu jsou čtyři segmentové pasy na piliřích připojené zvenčí k hlavní hradbě jižně od kaple, odkryté výkopem roku 1998. Jejich šiřka činí 3,5 m a jsou vyzděny z cihel

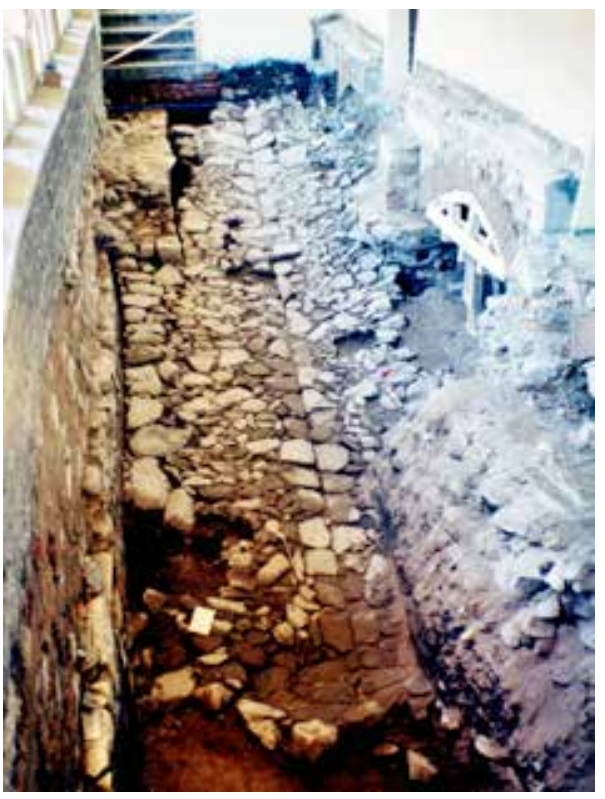

Obr. 20. Hrad Orlík, okr. Písek. Odvodňovací dlažba z konce 16. století, vlevo parkánová hradba z poloviny 14. století, vpravo cihlové pasy připojené při renesanční přestavbě ke gotické hlavní hradbě. Foto J. Varhaník, 1998.

Abb. 20. Burg Orlík, Bezirk Písek. Entwässerungspflasterung vom Ende des 16. Jahrhunderts, links Zwingermauer aus der Mitte des 14. Jahrhunderts, rechts die beim Renaissanceumbau mit Backsteingurten versehene Hauptwehrmauer. Foto J. Varhaník, 1998. formátu $31 \times 13,5 \times 7,5 \mathrm{~cm}$ s výjimkou severního výběhu posledního $\mathrm{z}$ nich, který zabíhá za klenbu sakristie, vložené do parkánu roku 1713 (Lancinger-Muk 1983, díl I., 13). Oblouky jsou rozepjaty mezi poměrně ledabyle provedenými pilíři, v jejichž zdivu bylo užito nízkých cihel pocházejících nejspíše z nějakých starších, rozebraných staveb. Pasy předstupují před líc hlavní gotické hradby o $66 \mathrm{~cm}$ a nesou skarpovitě skloněnou přizdívku. Celá poměrně složitá konstrukce souvisí zřejmě s nástavbou druhého patra. Téže stavební etapě náleží odvodňovací dlažba $v$ přilehlé části parkánu.

Pozoruhodným, avšak obtížně interpretovatelným jevem, zachyceným na obou věrnějších vyobrazeních hradu před požárem, jsou nevelké čtverhranné útvary, situované podle Bergera a Wolfa mezi okny druhého patra severozápadního průčelí v úrovni jejich horního okraje, u Janschy a Postla o něco níže na průčelí severovýchodním. Existence těchto detailů v dosavadní literatuře reflektována nebyla. Je zřejmé, že vzhledem $\mathrm{k}$ jejich četnosti a poloze nemůže jít o menší okénka. Nabízí se možnost, že snad mohlo jít o plastickou výzdobu průčelí, ovšem rozpaky vyvolává skutečnost, že obě průčelí se uplatňovala pouze $\mathrm{v}$ dálkových pohledech a príípadné detaily takovýchto reliéfů by tak nebyly viditelné. 


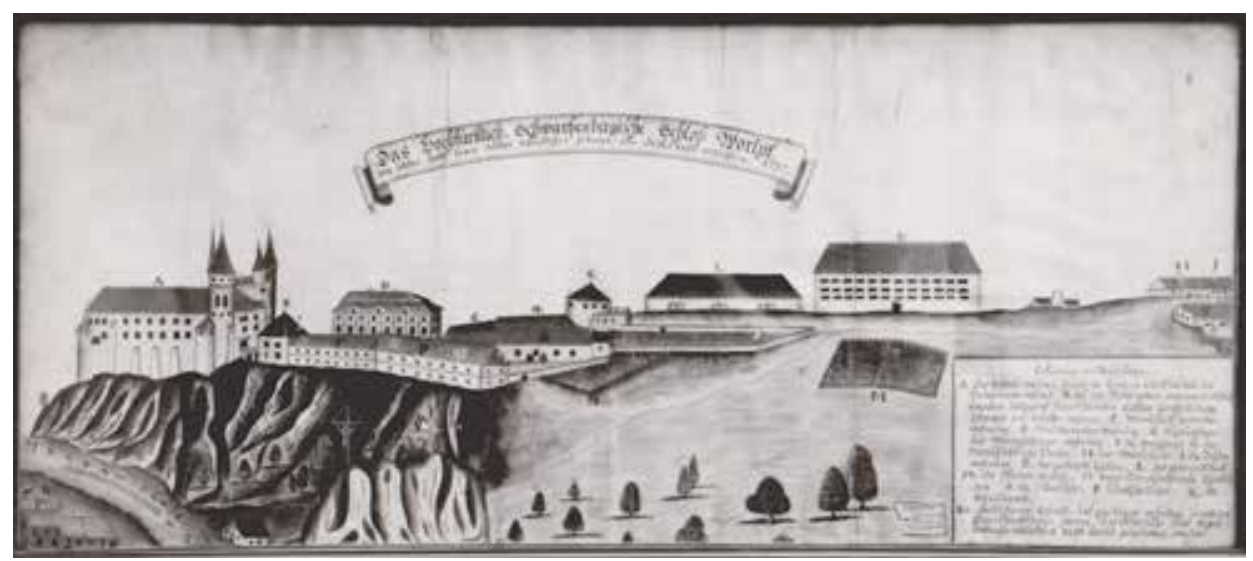

Obr. 21. Pohled na hrad Orlík s předhradím od severozápadu, rekonstrukce J. J. Planskera k roku 1737.

Abb. 21. Blick auf Burg Orlík mit Vorburg von Nordwesten, Rekonstruktion von J. J. Plansker zum Jahr 1737.

Kryštof (II.) se však dokončení přestavby nedočkal, nebot' zemřel v roce 1582. Jeho dědicem se stal Jan Jiř́i z ronšperské větve rodu (Jánský 2006, 369). Z roku 1585 jsou zprávy o výstavbě schodiště do druhého patra, jeho klenutí a zřizování krovu, přičemž se uvádí mistr Augustin neznámého původu. Práce pokračovaly ještě v roce 1592 (Lancinger-Muk 1983, díl I., 7-8). Je pravděpodobné, že tehdy byl zvýšen trakt nádvorních arkád, avšak o jeho podobě lze jen spekulovat na základě pozdních zmínek písemných pramenů.

V průběhu 16. století probíhala intenzivní stavební činnost v předhradí, avšak lokalizace jednotlivých objektů hospodářského určení je v důsledku jejího převrstvení početnou barokní zástavbou a po parkové úpravě v těchto místech bez archeologického výzkumu prakticky neproveditelná. Blíže lze určit pouze místo brány do předhradí, situované mezi klasicistními budovami tzv. zámečku a někdejších koníren, upravených na restauraci. Na jižním nároží předhradí se uplatňovala nevysoká okrouhlá věž (Sedláček 1936, 56, 64).

Po získání rožmberského dominia Janem Jiřím ze Švamberka dědictvím po Petru Vokovi význam Orlíka v rámci švamberských držav poněkud poklesl. V roce 1615 hrad převzal syn Jana Jiř́iho Petr, který se zanedlouho účastnil stavovského povstání jako jeden z direktorů (Lancinger-Muk 1983, díl I., 8), a po jeho porážce skončilo více než stoleté zdejší panování švamberského rodu. Téměř celá dvě následující století hrad sloužil jen jako hospodářské centrum panství nových majitelů.

\section{Závěr}

Hodnocení přestaveb hradu podniknutých v 16. století Švamberky nevyznívá zcela jednoznačně. Pozdně gotická přestavba hradu sice byla poměrně rozsáhlá, avšak její architektonická úroveň, jak lze $\mathrm{z}$ dochovaných detailů usuzovat, nikterak nevyčnívala $\mathrm{z}$ běžného průměru tehdejší stavební kultury a vykazovala spíše rustikální charakter, nedotčena vlivy význačných mistrů tehdejší doby. V př́ípadě dochovaných kružeb oken hradní kaple je kamenická práce dokonce spíše podprůměrná, což je u fanatického katolíka, jímž Kryštof (I.) byl, přinejmenším překvapující. Ve srovnání s formami poněkud starší aktivity téhož stavebníka na Boru u Tachova tak nová výstavba na Orlíku představuje zjevný krok zpět. Pohled na tehdejší podobu hradu je ovšem neúplný, nebot' postrádáme představu o výzdobě jeho interiérů.

Ještě obtížnější je hodnotit úroveň renesanční přsestavby. Na bohaté, avšak bohužel nedochované renesanční vybavení interiérů poukazují názvy zlatý, planetový a jelení sál, přičemž 
u posledního z nich J. Muk poukázal na možnou souvislost s jelením sálem na Bechyni (Lancinger-Muk 1983, díl II., 60). Renesanční Orlík zřejmě příliš nezaostával za tehdejšími ostatními jihočeskými zámky a zajisté zastiňoval poněkud starší poměrně skromné renesanční úpravy nedalekého, rovněž švamberského Zvíkova (Líbal b. d.).

Během prací prováděných $\mathrm{v}$ souvislosti se statickým zabezpečováním objektu bohužel nedošlo k dokumentaci odkrytých partií, a to jak v interiéru, tak v exteriéru, z nichž alespoň některé zajisté mohly podstatně doplnit poznatky o jeho stavebním vývoji, a podobně tomu bylo při opravě vnějších omítek. Kromě toho jsou zcela nedostatečné informace o zástavbě a materiální kultuře rozsáhlého předhradí, ovšem zásadním způsobem by je mohl doplnit případný archeologický výzkum.

\section{Prameny a literatura}

AČ II: Archiv český čili staré písemné památky české i moravské z archivů domácích i cizích II (Palacký, L., ed.). Praha 1842.

AČ XV: Archiv český čili staré písemné památky české i moravské z archivů domácích i cizích XV (Kalousek, J., ed.). Praha 1896.

BENEŠ, J., 2000: Archeologický výzkum hradu Orlíka nad Vltavou v roce 1998, nálezová zpráva - aktualizovaná verze, ulož. v archivu autora.

BRODIE, H., 2015: Apsidel and D-shaped towers of the Princes of Gwynedd, Archaeologia Cambrensis $164,231-243$.

BŘICHÁČEK, P., 1989: Záchranný výzkum na hradě Orlíku nad Vltavou (o. Písek) - Rettungsforschung auf der Burg Orlík a.d. Moldau, CB 1, 331-333.

BUDINKA, Z., 1959: Záchrana a technické zabezpečení památkových objektů v zátopové oblasti vodního díla Orlík, ZPP XIX, 119-138.

DURDÍK, T., 1979: Nástin vývoje českých hradů 12.-13. století - Enwicklungsskizze böhmischer Burgen aus dem 12.-13. Jahrhundert, AH 3, 41-52.

- 1994: Kastellburgen des 13. Jahrhunderts in Mitteleuropa. Praha.

- 1995: Encyklopedie českých hradů. Praha.

- 1997: Hrady kastelového typu 13. století ve střední Evropě. Praha.

- 1999: Ilustrovaná encyklopedie českých hradů. Praha.

DURDÍK, T.-ADÁMEK, J.-FRÖHLICH, J.-CHOTĚBOR, P., 1998: Vybrané středověké památky Prácheňska. Praha.

- 1998a: Castrum Bene 6. Exkursionführer. Praha - Písek.

DURDÍK, T.-KAŠIČKA, F.-NECHVÁTAL, B., 1995: Hrady, hrádky a tvrze na Písecku. Písek.

FUKA, Z., 1978: Hrad Orlík, statický průzkum, průvodní zpráva, strojopis SÚRPMO, ulož. v archivu Národního památkového ústavu, odborného územního pracoviště v Českých Budějovicích.

GRABOLLE, R.-HRUBÝ, P.-MILITKÝ, J., 2002: Orlík nad Vltavou ve 13.-14. století ve světle archeologického výzkumu - Orlík nad Vltavou (Worlik) im 13. und 14. Jahrhundert im Licht der Archäologischen Forschung, AH 27, 91-118.

JÁNSKÝ, J., 2006: Páni ze Švamberka. Pětisetletá sága rodu s erbem labutě - Die Herren von Švamberk (Schwanberg). Domažlice.

KOSTKA, J.-HANESCH, J., 1956: Orlík, státní hrad a okolí. Praha.

LANCINGER, L.-MUK, J., 1983: Orlík, stavebně historický průzkum státního hradu, SÚRPMO, strojopis ulož. v archivu Národního památkového ústavu, odborného územního pracoviště v Českých Budějovicích.

- 1994: Stavební vývoj hradu Orlíka nad Vltavou - Die Bauentwicklung der Burg Orlík an der Moldau, CB 4, 89-94.

LÍBAL, D., b. d.: Zvíkov. Praha.

MENCLOVÁ, D., 1972: České hrady 1, 2. Praha.

NOVÁČEK, V. J., 1890: Dětřich z Portic, přední rádce Karla IV., Časopis musea království českého LXIV, 459-535.

NOVÁK, J. B., 1903: Formulář Tobiáše z Bechyně. Hist. archiv ČAVU XXII. Praha.

SEDLÁČEK, A., 1936: Hrady, zámky a tvrze království českého XI. Praha.

RADOVI, M. a O., 1998: Kniha o sklípkových klenbách. K 500. výročí sklípkového klenutí v Evropě. Praha. THIR, K., 1920: Staré domy a rodiny táborské II. Tábor. 
VARHANÍK, J., 1998: Husitské opevnění hradu Orlíka - Hussitische Befestigung der Burg Orlík an der Moldau, PRP 5, č. 1, 13-32.

- 2002: Obrana středověkého hradu palnými zbraněmi - Die Verteidigung der mittelalterlichen Burg mit dern Feuerwaffen, AH 27, 125-138.

- 2014: Arkádové nádvoří hradu Orlíka nad Vltavou - Arkadenhof des Schlosses Orlík (Bez. Písek). In: Dějiny staveb 2014. Sborník příspěvků z konference Dějiny staveb, 23-30. Plzeň.

VELÍMSKÝ, T., 2013: Páni ze Svojšína. Ústí nad Labem.

ZÁRUBA, F., 2016: Hradní kaple III., doba poděbradská a jagellonská - Die Burgkapellen des 15. und der ersten hälfe des 16. Jahrhunderts. Praha.

\section{Zusammenfassung}

\section{Die baulichen Veränderungen von Burg Orlík nad Vltavou im 16. Jahrhundert}

Die ursprüngliche Königsburg Orlík wurde auf einem hohen Felssporn oberhalb der Moldau errichtet, deren Flusstal in den Jahren 1960-1961 mit der Orlík-Talsperre geflutet wurde. Vom Vorfeld war der Felssporn durch einen massiven Felsausstrich abgetrennt. In dem komplizierten Bauorganismus des Objektes scheint die älteste Burg wahrscheinlich eine Burganlage mit einem Bergfried in Form eines Rundturms an der höchsten Stelle der Baufläche zu sein, von dem jedoch nur das Negativ eines Teils seines Mantels im Bereich der späteren Küche übrig geblieben ist. Um Mitte des 14. Jahrhunderts wurde die Burg von einer 1,5 m starken Zwingermauer umschlossen und gleichzeitig kam es zu einer wesentlichen Vergrößerung der Wohnräume. $\mathrm{Zu}$ Beginn des 15. Jahrhunderts wurde an der Burgvorderseite eine neue Befestigungsanlage mit hoher Schildmauer und einem Batterieturm links vom Eingang gebaut.

Nach einem Brand im Jahr 1508 erwarb Christoph von Schwanberg die Burg, der in den Jahren 1515-1520 einen umfangreichen Umbau durchführte. Auf der Schildmauerkrone wurde ein kleinerer dritter Turm errichtet. Vor dem Tor baute man an die Außenflucht der Schildmauer einen engen Trakt an. Links vom Eingang wurde eine mit dem Erdgeschoss des Batterieturms verbundene Pforte errichtet. Völlig neu gebaut wurde der Nordwestflügel mit eingewölbten Kellern und ebensolchem Erdgeschoss, das erste Stockwerk wurde mit einer Flachdecke versehen. In der Mitte des Erdgeschosses ist ein kleiner Raum mit einfachem Zellengewölbe erhalten geblieben. Die Hofarkaden wurden um eine Futtermauer erweitert, was darauf hindeutet, dass im ersten Stock ein Arkadengang aus Stein errichtet wurde. Es ist nicht sicher, ob es damals zu einem völligen Neubau der Kapelle im Südostflügel gekommen war, oder ob die ältere Kapelle nur umgebaut wurde. Von den spätgotischen Bau sind nur einige kleine Portale mit flacher Profilierung und analytisch anerkannten Fensterlaibungen erhalten geblieben sind.

Der Renaissanceumbau umfasste den Bau eines zweiten Stockwerks. Südlich von der Kapelle wurden am Graben im Zwinger Segmentstreifen an den Pfeilern entdeckt, welche die offenbar mit dem Bau des zweiten Stockwerks zusammenhängende Futtermauer getragen haben. Der Zwinger wurde dort mit einer Entwässerungspflasterung versehen. Infolge der einzelnen im 18. Jahrhundert erfolgten Barockumbauten, des Brandes von 1802 und der anschließenden klassizistischen Umbauten sind die reichen Innenräume der Renaissancezeit - von denen der Gold-, Planeten- und Hirschsaal erwähnt werden - nicht erhalten geblieben. Die umfangreiche, im Barock überlagerte und im 19. Jahrhundert während des Zwingerumbaus verschwundene Bebauung ist lediglich aus den Erwähnungen in den schriftlichen Quellen bekannt.

JUDr. Jiří Varhaník, Orlík nad Vltavou 26, 39807 Orlík nad Vltavou, Česká republika, jiri.varhanik@gmail.com 
